\title{
ГЕОЛОГІЯ
}

UDC 622.337.2:553.98.061.17

Adil A. Aliyev,

Doctor of Sciences (Geology and Mineralogy), Professor,

Head of Department of Mud Volcanism, Institute of Geology and Geophysics,

Azerbaijan National of Academy Sciences, H. Javid ave., 119, Baku, AZ1143, Azerbaijan, e-mail: ad_aliyev@mail.ru, https://orcid.org/0000-0002-7731-9525;

Orhan R. Abbasov,

$\mathrm{PhD}$ (Earth Sciences), Associate Professor, Senior Researcher of Department of Mud Volcanism, Institute of Geology and Geophysics, Azerbaijan National of Academy Sciences,

H. Javid ave., 119, Baku, AZ1143, Azerbaijan,

e-mail: ortal80@bk.ru, http://orcid.org/0000-0003-2135-7984;

Agamehdi M. Agayev,

$\mathrm{PhD}$ (Chemical Sciences), Associate Professor of Faculty of Geological Exploration,

Azerbaijan State Oil and Industry University, Azadlig ave., 20, AZ1010, Baku, Azerbaijan, e-mail: agamehti.agaev@ gmail.com, https://orcid.org/0000-0003-1195-1971

\section{MINERALOGY AND GEOCHEMISTRY OF OIL SHALE IN AZERBAIJAN: CLASSIFICATION, PALAEOWEATHERING AND MATURITY FEATURES*}

Ад. А. Алиев, О. Р. Аббасов, А. М. Агаев. МИНЕРАЛОГИЯ И ГЕОХИМИЯ ГОРЮЧИХ СЛАНЦЕВ В АЗЕРБАЙДЖАНЕ: КЛАССИФИКАЦИЯ, ОСОБЕННОСТИ ПАЛЕОВЫВЕТРИВАНИЯ И ЗРЕЛОСТИ. В научно-исследовательской работе широко рассмотрены наземные выходы горючих сланцев Шамахы-Гобустанского и Апшеронского районов, а также среди выбросов грязевых вулканов Азербайджана. В соответствии с распространением в породах как главных, так и микроэлементов, на основании опубликованных материалов был проведен сравнительный анализ со средними, среднечерными сланиами, составом сланцев Северной Америки, пост-архейскими сланцами Австралии, а также горючими сланцами Эстонии, Иордании, США и др. На основе известных классификаций рассматриваются характеристики стабильности оксидов главных элементов и оиениваются признаки зрелости. Свойства выветривания широко прокомментированы на основании различных индексов, в том числе «Индекса изменения в соответствии с компонентом (ИИСК)», «Индекса химических изменений (ИХИ)», а также анализами результатов диаграмм, связанных с элементным составом.

В составе образиов определено 11 минералов 5 классов, в которых преобладают силикаты. Используемая классификаиионная диаграмма $\log \left(\mathrm{SiO}_{2} / \mathrm{Al}_{2} \mathrm{O}_{3}\right)$ и $\log \left(\mathrm{Fe}_{2} \mathrm{O}_{3} / \mathrm{K}_{2} \mathrm{O}\right)$ показывает, что все исследованные образиы соответствуют сланиам.

Соотночение $\mathrm{K}_{2} \mathrm{O}_{\mathrm{A}} \mathrm{I}_{2} \mathrm{O}_{3}$ подтверждает превосходство глинистых минералов в составе горючих сланиев по сравнению с K-минералами, включая $\mathrm{K}$-полевой шпат. Оиенки на основе $\mathrm{Al}_{2} \mathrm{O}_{3} /\left(\mathrm{CaO}+\mathrm{MgO}+\mathrm{Na}_{2} \mathrm{O}+\mathrm{K}_{2} \mathrm{O}\right)$ и $\mathrm{Fe}_{2} \mathrm{O}_{3} / \mathrm{K}_{2} \mathrm{O}_{2} \mathrm{SiO}_{2} / \mathrm{Al}_{2} \mathrm{O}_{3}$

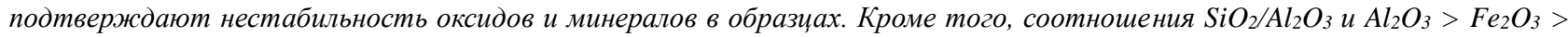
$\mathrm{TiO}_{2}$ подтверждают незрелость и связь с глинистыми минералами.

Значения ИХИ и диаграммы зависимости ИХИ от ИИСК, ИХИ от Al/Na и A-CN-K, а также исследования, связанные с содержанием главного оксида, подтверждают среднюю и высокую степень выветривания. Протолит сланиев связан с мафическими и промежуточными изверженными источниками.

Ключевые слова: горючие сланиы, геохимия, минерал, классификация, зрелость, выветривание.

АӘ. А. Алісв, О. Р. Аббасов, А. М. Агаєв. МІНЕРАЛОГІЯ І ГЕОХІМІЯ ГОРЮЧИХ СЛАНЦІВ В АЗЕРБАЙДЖАНІ: КЛАСИФІКАЦІЯ, ОСОБЛИВОСТІ ПАЛЕОВИВІТРЮВАННЯ І ЗРІЛОСТІ. У науково-дослідній роботі широко розглянуті наземні виходи горючих сланиів Шамах-Гобустанський $і$ Апшеронського районів, а також серед викидів грязьових вулканів Азербайджану. Відповідно до поширення в породах як головних, так і мікроелементів, на підставі опублікованих матеріалів був проведений порівняльний аналіз із середніми, середньо-чорними сланцями, складом сланців Північної Америки, пост-архейськими сланиями Австралії, а також горючими сланиями Естонії, Йорданії, США та ін. На основі відомих класифікаиій, розглядаються характеристики стабільності оксидів головних елементів і оцінюються ознаки зрілості. Властивості вивітрювання широко прокоментовані на підставі різних індексів, в тому числі «Індекса зміни відповідно до компонента (IЗBK)», «Індекса хімічних змін (IX3)», а також аналізами результатів діаграм, пов'язаних з елементним складом.

У складі зразків визначено 11 мінералів 5 класів, в яких переважсають силікати. Використовувана класифікаційна діаграма $\log \mathrm{SiO}_{2} / \mathrm{Al}_{2} \mathrm{O}_{3}$ i $\log \left(\mathrm{Fe}_{2} \mathrm{O}_{3} / \mathrm{K}_{2} \mathrm{O}\right)$ показує, щзо всі досліджені зразки відповідають сланиям.

Співвідношення $\mathrm{K}_{2} \mathrm{O} / \mathrm{Al}_{2} \mathrm{O}_{3}$ підтверджуе перевагу глинистих мінералів у складі горючих сланців в порівнянні з $\mathrm{K}$ мінералами, включаючи $\mathrm{K}$-польовий шпат. Очінки на основі $\mathrm{Al}_{2} \mathrm{O}_{3} /\left(\mathrm{CaO}+\mathrm{MgO}+\mathrm{Na}_{2} \mathrm{O}+\mathrm{K}_{2} \mathrm{O}\right)$ i $\mathrm{Fe}_{2} \mathrm{O}_{3} / \mathrm{K}_{2} \mathrm{O}, \mathrm{SiO}_{2} / \mathrm{Al}_{2} \mathrm{O}_{3}$

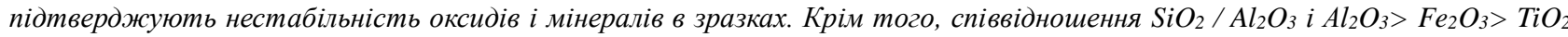
підтверджують незрілість $і$ зв 'язок з глинистими мінералами.

Значення IX3 і діаграми залежності IX3 від IЗBK, IX3 від Al / Na i A-CN-K, а також дослідження, пов'язані з утриманням головного оксиду, підтверджують середню і високу ступінь вивітрювання. Протоліт сланців пов'язаний з мафічними $і$ проміжними виверженими джерелами.

Ключові слова: горючі сланиі, геохімія, мінерал, класифікаиія, зрілість, вивітрювання.

(C) Aliyev A. A., Abbasov O. R., Agayev A. M.

https://doi.org/10.26565/2410-7360-2019-50-01 
Introduction. The South Caspian Basin (SCB) is located in the collision zone between the Arabian and Eurasian plates which is subjected to intensive sedimentation. Such tectonic and paledepositional features have created a favorable condition for the formation of hydrocarbons, mud volcanoes, especially oil shale in the Paleogene-Miocene sediments in Shamakhi-Gobustan and Absheron regions.

About 60 oil shale manifestations and deposits were recorded in these regions [41]. Along with outcrops, oil shale is also found in ejecta of mud volcanoes, which are widely spread both in ShamakhiGobustan and Absheron regions $[1 ; 3 ; 4 ; 10 ; 22]$.

The study is aimed to investigate the chemical classifications, provenience, palaeoweathering and maturity characteristics of oil shale in the research regions based on the geochemical and mineralogical features.

Analysis of recent research and publications.

Information about oil shale in Azerbaijan is known as early as the beginning of the 20th century. This information was brief, because researchers, especially Russian scientists described only the outcrops of oil shale recorded during the study of the geological structure, tectonic properties and hydrocarbon potential of the territory of Azerbaijan [1].

In the middle of the century, the investigations on the study of oil shale have been relatively expanded, and several scientific papers and reports related to some fields and manifestations have been published $[1 ; 3 ; 5 ; 6 ; 10 ; 22]$.

In later periods, the question of the study of non-traditional oil shale in Azerbaijan has not been enough actual. Of course, the main reason for this was the existence of large reserves of oil and gas in the territory of the Republic [1].

Since the beginning of 2000 , the issue of studying oil shale has been resumed in the Department of "Mud Volcanism" of the Institute of Geology and Geophysics, Azerbaijan National Academy of Sciences. The geological and organic-geochemical features, as well as the probable resources and using the potential of oil shale of the Shamakhi-Gobustan, Absheron, Guba, Ismayilli regions of Azerbaijan, have been widely commented in the papers of a number of scientists of the Department $[1-6 ; 9 ; 10$; $12-14 ; 22 ; 41]$.

There are no any available studies conducted by Azerbaijani and foreign researchers that have been devoted to issues such as mineralogy, classification, provenance, etc. based on the inorganic chemical properties of oil shale found in PaleogeneMiocene sediments in the country. Though there are many published literature devoted to these studies in countries where oil shale has long been investigated $[8 ; 15 ; 17 ; 28 ; 30 ; 38 ; 44 ; 45]$. In this regard, this study is the first attempt to investigate the classifications, provenience, palaeoweathering and maturity characteristics of oil shale in Azerbaijan.

Geological settings. Shamakhi-Gobustan region - occupies a significant part of the south- eastern plunge of the Greater Caucasus. The Meso- Cenozoic and Quaternary formations take part in the geological structure of the region [1;11]. About 40 outcrops of oil shale associated with Upper Cretaceous-Miocene sediments were registered here $[5 ; 6$; $22 ; 41]$. The layers of oil shale of the Upper Cretaceous are thin, and the content of organic matter is relatively low $[1 ; 2]$. The region is characterized by a change in the thickness of sediments of the Middle Eocene. The thickness of oil shale layers vary in intervals of up to 10 meters in arches of the anticline, synclinal and mould structures (Boyuk Siyaki, Kichik Siyaki, Jangichay, Jangidagh, etc.) [1;9]. The layers, containing oil shale in sediments of the Upper Maikopian are associated with shale lithofacies of the "Riki horizon". The sediments of the Middle Miocene (Konkian) are characterized by light gray, brown-gray shale and carbonate rocks. In the northwest and southwest of Gobustan, these lithofacies alternate with layers of oil shale of various thicknesses. The layers of oil shale were also registered in the sections of the Upper Sarmatian sediments $[6 ; 10]$.

The geological and tectonic positions of the region are very complex, and two microblocks (Bayanata and Toragay) were established here that bound to the Goradil-Masazir underthrust zone and GujurGyzyldash thrust [11].

Absheron region - 18 outcrops of oil shale were registered in the region [41]. In the geological structure of the region, the terrigenous and carbonate rocks of the Upper Cretaceous and Cenozoic deposits are noted [11]. Oil shale in the sections of the Eocene was registered only in the areas of Goytepe and Govundag [6]. The sediments containing oil shale in the region are associated mainly with the Upper Maikopian series and Upper Miocene [2; 5 ; 9]. The alternation of layers of black bituminous oil shale is registered on the northern slope of the mountains Uchtepe-Shorchala, as well as in the outcrops of the mountains Goytepe, Orjandagh and Fatmai. In the terrigenous and carbonate sediments of the Middle Miocene, the shale-bearing layers with a thickness of $30 \mathrm{~m}$ were observed within the Western Absheron in the Shorbulag and Garaheybat areas. The outcrops of laminated oil shale were recorded in Uchtepe-Ilkhidagh area, within the southern pericline of the Kecaldagh-Zigilpiri fold and further east of the village of Binagadi. The outcrops of oil shale were recorded in the Meotian sections that are characterized by a different thickness 
in the region. Due to tectonic and orographic settings, the region is a bottom of the south-eastern part of the Greater Caucasus. Most of the tectonic zones are gradually deepening in the direction of the expansion of the Greater Caucasus - from the northwest to the south-east, and complicated with mud volcanoes (Keyreki, Lokbatan, Bozdagh-Qobu, etc.) [11]. The samples of oil shale were taken from the outcrops of Jangichay and Boyuk Siyaki of the central part of Shamakhi-Gobustan region, as well as from ejecta of mud volcanoes in the studied regions (Fig. 1).

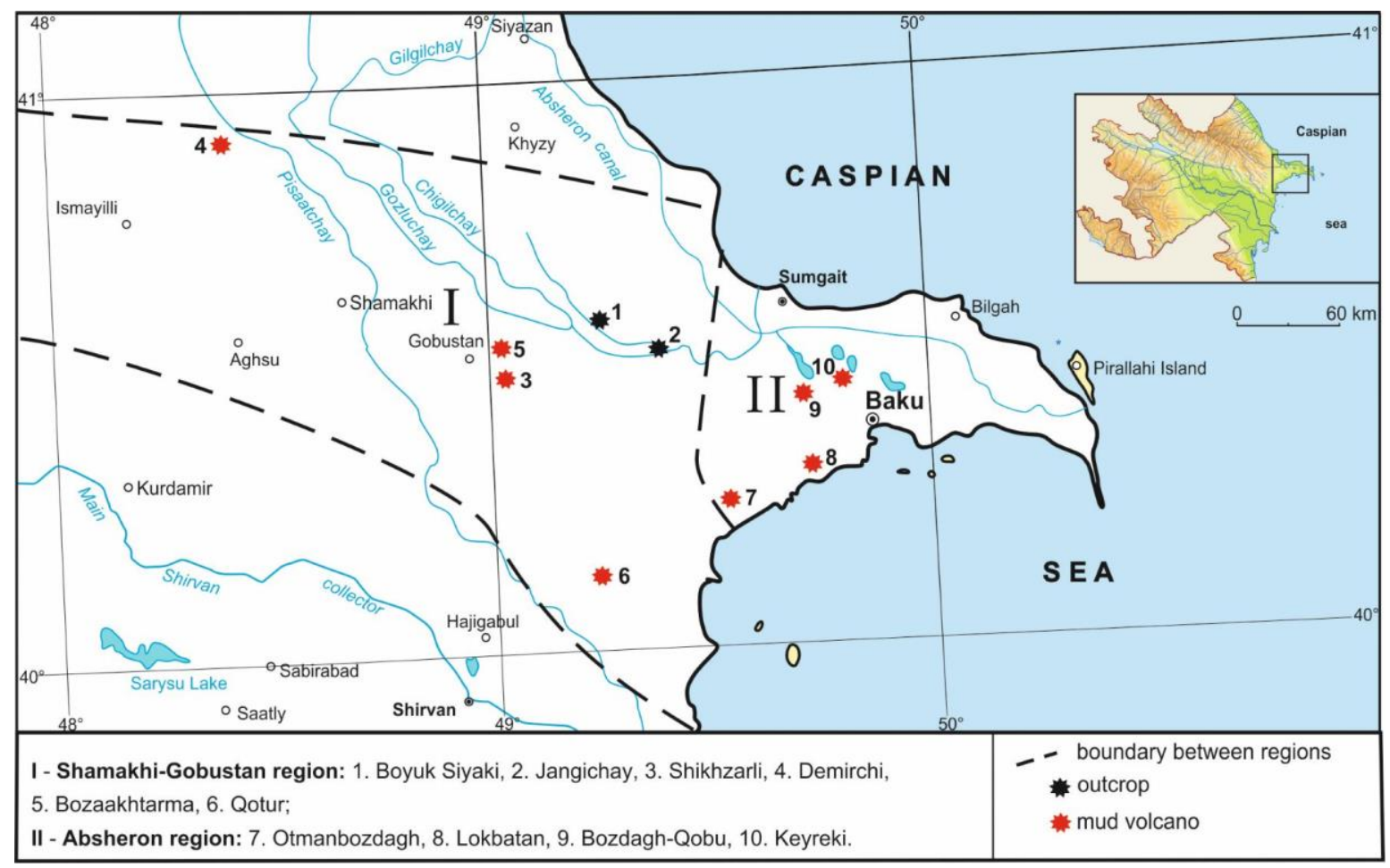

Fig. 1. Location map of the studied oil shale from outcrops and mud volcanoes

The accuracy of the age of oil shale from the outcrops is beyond doubt. Thus, the geological structure of the studied areas has been studied accurately. The geological age of oil shale found in the ejecta of mud volcanoes was determined according to the genus and species of fauna contained in the rocks assemblages. The Globigerina bulloides (Orbigny), Cibicides sp., Globigerina triloculinoides (Plummer), etc. planktonic and benthic foraminifera belonged to Eocene were determined in the studied rocks.

Materials and methods. Samples - two samples from the outcrops (1 - Boyuk Siyaki, 2 - Jangichay) and eight samples from ejecta of mud volcanoes (3 - Shikhzarli, 4 - Demirchi, 5 - Bozaakhtarma, 6 - Qotur, 7 - Otmanbozdagh, 8 - Lokbatan, 9 - Bozdagh-Qobu, 10 - Keyreki) were taken. The samples are black, gray and brown in color with a laminated structure.

Chemical composition of rocks - analysis of major element oxides were performed on the "S8 TIGER Series 2 WDXRF" spectrometer and trace elements on the "Agilent 7700 Series ICP-MS" mass spectrometer at the Institute of Geology and Geophysics, Azerbaijan National Academy of Sciences.
Mineralogical composition of rocks - studied using the XRD "MiniFlex 600" at the same Institute.

Age of rocks - the microscopes "Loupe Zoom Paralux XTL 745" and "МБC-10" and a digital camera "OptixCam" were used. The study was carried out at the Integrated Engineering Exploration Production, Department of Geophysics and Geology, SOCAR.

Methodology. The published literature was used to obtain information about average shale [47], average black shale [49], North American shale composite [25], post-Archean Australian Shale [46] as well as oil shale from the Green River Formation of USA [45], Gurun basin and Hatildag deposit of Turkey [38; 44], Sultani deposit of Jordan [8], Baltic deposit of Russia [28] and Estonia deposit of Estonia [15] for comparative studies based on the distribution of major oxides and trace elements. A diagram and index proposed by [27] and [24] were used for the classification and determination of maturity of samples. The palaeoweathering characteristics were studied based on two indexes - Index of Compositional Variability [18] and Chemical Index of Alteration [35], and also plots proposed by [18; $31 ; 35 ; 43]$. 
Results and discussions. Mineralogy -11 minerals belonging to 5 classes: mainly carbonates, sulphates and silicates were found in the samples.
Only one sample contains $1 \%$ of halite (halogen class), and hematite was found in three samples (Table 1).

Mineralogical composition of samples (\%)

Table 1

\begin{tabular}{|c|c|c|c|c|c|c|c|c|c|c|c|c|}
\hline Region & $\begin{array}{c}\text { Area } \\
\text { (sample) }\end{array}$ & 节 & $\begin{array}{l}0 \\
\frac{0}{2} \\
\frac{0}{0} \\
\frac{0}{0}\end{array}$ & $\frac{\mathscr{n}}{\frac{0}{\pi}}$ & $\stackrel{\mathscr{\Xi}}{\Xi}$ & 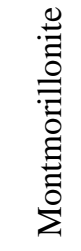 & $\frac{.}{\frac{0}{0}}$ & 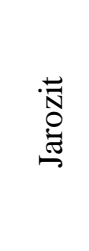 & 穿 & $\begin{array}{l}\stackrel{0}{\overrightarrow{0}} \\
\stackrel{0}{0}\end{array}$ & 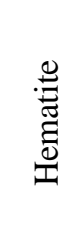 & 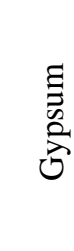 \\
\hline \multirow{6}{*}{ 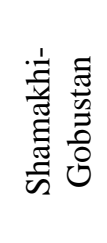 } & Boyuk Siyaki (1) & 26.7 & 10.0 & 2.0 & 9.0 & 10.0 & 15.0 & 1.5 & - & 25.8 & - & - \\
\hline & Jengichay (2) & 28.0 & 6.0 & 8.0 & 10.0 & 13.0 & 20.0 & 15.0 & - & - & - & - \\
\hline & Shikhzarli (3) & 23.0 & 7.0 & - & 15.0 & 15.0 & 20.0 & 20.0 & - & - & - & - \\
\hline & Demirchi (4) & 28.0 & 13.0 & 4.0 & 15.0 & 15.0 & 18.0 & 4.0 & - & - & 3.0 & - \\
\hline & Bozaakhtarma (5) & 27.0 & 5.0 & - & 7.0 & 26.0 & 10.0 & 22.0 & - & 3.0 & - & - \\
\hline & Qotur (6) & 23.0 & 5.0 & 12.0 & 10.0 & 12.0 & 16.0 & 16.0 & 1.0 & - & - & 5.0 \\
\hline \multirow{5}{*}{$\begin{array}{l}\tilde{0} \\
\frac{0}{0} \\
\frac{\pi}{0} \\
\frac{0}{4}\end{array}$} & Otmanbozdagh (7) & 20.0 & 15.0 & 9.0 & 12.0 & 17.0 & 17.0 & 7.0 & - & - & - & - \\
\hline & Lokbatan (8) & 23.0 & 5.0 & 14.0 & 10.0 & 16.0 & 15.0 & 17.0 & - & - & - & - \\
\hline & Bozdagh-Qobu (9) & 35.0 & 8.0 & 3.0 & 11.0 & 12.0 & 16.0 & 12.0 & - & - & 3.0 & - \\
\hline & Keyreki (10) & 24.0 & 8.0 & 18.0 & 10.0 & 15.0 & 15.0 & 4.0 & - & - & 6.0 & - \\
\hline & Mean & 25.8 & 8.2 & 7.0 & 10.9 & 15.1 & 16.2 & 11.8 & 0.1 & 2.9 & 1.2 & 0.5 \\
\hline
\end{tabular}

The analyze of mineral assemblages in the shale samples showed the presence of clay minerals - illite, chlorite and montmorillonite. The value of montmorillonite $($ mean $=15.1 \%)$ and chlorite $($ mean $=16.2 \%)$ higher than illite $($ mean $=10.9 \%)$ (Table 1).

Illite is widely distributed in clay and shale associated with the marine origin as a result of weathering of feldspar and muscovite. In the process of converting muscovite to illite, some part of $\mathrm{K}^{+1}$ is replaced by $\mathrm{Ca}^{+2}, \mathrm{Mg}^{+2}$ and $\mathrm{H}_{3} \mathrm{O}^{+}$[7]. On the other hand, in a process of metamorphism of clay, its crys- tallization provides an indicator between diagenesis and low-temperature metamorphism [23].

Chlorites are formed in a result of physical and chemical change in the minerals of a mafic type such as pyroxene, amphibole, biotite, talc, and pyrophyllite. In coastal areas, where the degree of metamorphism is low, iron-enriched chlorite is formed. This type of chlorite is more unstable. At low temperatures, chlorite converts to montmorillonite, while and at high temperatures to talc, cordierite and garnet [7].

Montmorillonite belonging to the group of smectite forms as a result of hydrothermal changes or weathering of aluminum-rich minerals, in particular, bentonites - volcanic ash and tuff. Formation of this mineral often occurs together with other clay minerals, including illite. In the process of formation, the role of weathering and transformation of aluminosilicate rocks, especially, feldspar as well as rivers and streams are not excluded [29]. This mineral is an authigenic, and its origin related

to an accumulation of shale and a change in detrital materials in a relatively calm condition.

The mean value of quartz in samples is $25.77 \%$, feldspar $-8.2 \%$ (Table 1). Quartz is a wide- spread accessory mineral associated with siliceous eruptions, such as volcanic rhyolite and plutonic granite [33]. Taking part in all degrees of metamorphism, and having a high resistance to chemical weathering, this mineral is widely distributed in sedimentary rocks including metamorphosed oil shale.

Anorthite (Fig. 2a and 2c) and albite (Fig. 2b and $2 \mathrm{~d}$ ) are present in the studied samples. Anorthite is the calcium-rich endmember of the plagioclase solid solution series, the other endmember being albite (the sodium endmember). Albite twinning is characteristic for plagioclase associated with igneous rocks, such as basalt, andesite, dacite, rhyolite, etc. Along with the metamorphic rocks, they are found in the composition of detrital sedimentary rocks. At shallow depths, close to the Earth's surface, they are relatively less stable in comparison with alkaline feldspar (orthoclase, anorthoclase, etc.) and quartz, and decompose to clay mineral during weathering [33]. Quartz and feldspar are associated with coastal zones [29]. During diagenesis, various processes occur in sediments, such as activation of silicate source for quartz cementation, as well as a replacement of quartz and feldspar with calcite or clay transformation $[26 ; 42]$.

The mineral calcite (carbonate class) was found in eight rock samples (mean $=7.0 \%)$ and siderite in only two samples $($ mean $=2.9 \%)($ Table 1$)$. The ma- 

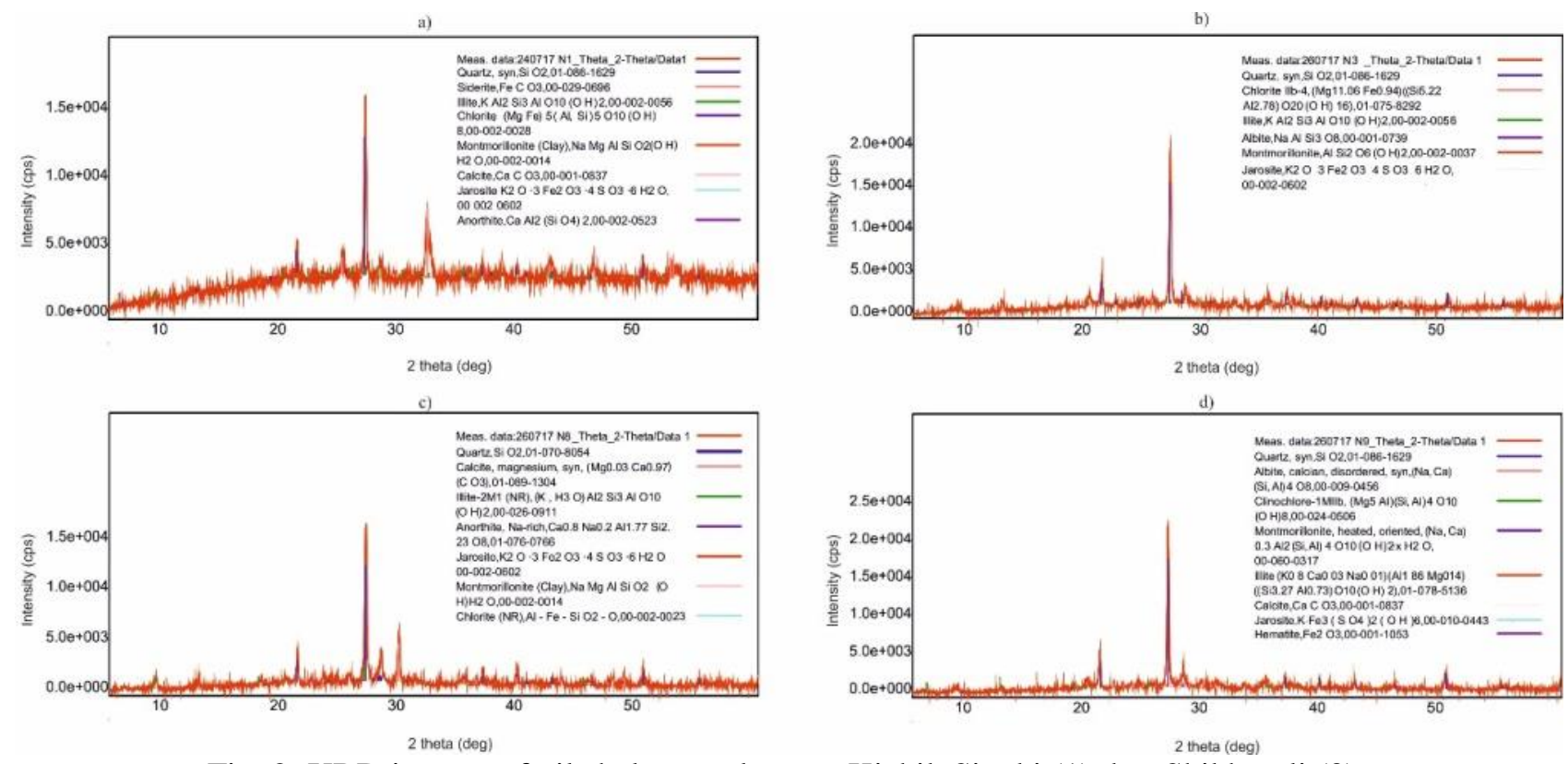

Fig. 2. XRD images of oil shale samples: a - Kichik Siyaki (1), b - Shikhzarli (3), c - Lokbatan (8), d - Bozdag-Qobu (9)

in components of carbonate minerals are limestone and dolomite. The main element structure center of the carbonate minerals consists of an equilateral triangle in which a $\mathrm{C}^{+4}$ ion is located, and oxygen ions in its hills. Each $\mathrm{Ca}^{+2}$ ion is surrounded by six oxygen ions. The carbonate minerals, found as a result of analytical studies, belong to the calcite group. Calcite is the most common carbonate mineral, mainly consist of limestones that their fine-grained powder as a cementing agent plays a key role in the formation of sedimentary rocks, oil shale and skeletal structures of living organisms. This group of mineral is associated with rare products of magmatic eruptions called carbonatites. They form as a veinlet associated with sulphide ores after precipitation from hydrothermal fluids. Unlike calcite, aragonite forms as a result of high pressure and temperature related to depths close to the surface. According to this feature, the presence of the aragonite mineral in metamorphic oil shale can be considered as an indicator of metamorphism, reflecting a condition of low temperature and high pressure. In terms of temperature, a relatively hot paleosource is characterized by aragonite, and cold by calcite [33]. The common genesis of calcite mineral identified in the samples is bound to cold sources. Another calciumcontaining mineral is diagenetic siderite, often presents in the composition of oil shale and sandstone. Forming in shallow water and taking part in the formation of concretion, this mineral gives a reason to take this factor into account during the study of the genesis of oil shale.

A widespread mineral of sulphate class in the content of samples is jarosite, with an average value of $11.85 \%$. In addition, $5 \%$ of gypsum was found in sample No. 6. Jarosite is an alunite group mineral, which is the main potassium and iron hydrosulfite. The mineral is considered as a secondary mineral associated with the oxidized part of sulphidecontaining rocks. The genetic feature of this mineral related to a weathering occurring in an arid climate. This mineral often forms due to weathering of iron sulphide. Gypsum is an aqueous sulfate of calcium. As a less dense mineral, genetically forms in a lake, sea and geothermal water as well as also in a veinlet that is rich in sulphate precipitation.

Unlike magnetite, hematite is more prone to oxidation and can be considered a changing product of magnetite. In many igneous rocks, hematite is a solid solution in the composition of ilmenite. Larger sediments of hematite are found in strip-like iron formations. The mineral origin is associated with geothermal waters, as well as with stagnant water environments at the bottom of the lakes, sometimes anhydrous conditions and volcanic activity [33].

Major oxides. The $\mathrm{SiO}_{2}$ value in the samples ranges from 45.72 to $55.55 \%$ (mean $=49.81 \%$ ). The values of this major oxide in the samples taken from the Boyuk Siyaki and Jangichay outcrops differ from oil shale sampled from ejecta of mud volcanoes in Shamakhi-Gobustan region. A tendency on decreasing of the value for this oxide was recorded towards the south-east from North Gobustan. In addition to $\mathrm{Si}$, the second major oxide in the chemical composition of samples is Al. It is nearly impossible to give statistical distributions for this element on the studied areas and regions. The $\mathrm{Al}_{2} \mathrm{O}_{3}$ values in the samples range from 12.69 to $16.81 \%$ (mean = $14.64 \%)$. Compared to the Eocene samples, the $\mathrm{Fe}_{2} \mathrm{O}_{3}$ value is significantly higher $(13.54 \%)$ in 
sample No. 1 of the Upper Miocene. The $\mathrm{Fe}_{2} \mathrm{O}_{3}$ values are significantly lower (4.92-8.54\%) in the other nine samples.

The mean value of $\mathrm{Fe}_{2} \mathrm{O}_{3}$ is $6.84 \%$. Other major oxides, such as $\mathrm{Na}_{2} \mathrm{O}(0.97-1.76 \%$, mean $=1.34$ $\%), \mathrm{MgO}(2.25-3.20 \%$, mean $=2.65 \%), \mathrm{P}_{2} \mathrm{O}_{5}$
$(0.03-0.39 \%$, mean $=0,17 \%), \mathrm{SO}_{3}(0.35-7.37 \%$, mean $=2.93 \%), \mathrm{K}_{2} \mathrm{O}(2.06$ to $3.89 \%$, mean $=3.36$ $\%), \mathrm{CaO}(0.29-9.67 \%$, mean $=3.97 \%), \mathrm{TiO}_{2}$ $(0.61-0.90 \%$, mean $=0.76 \%), \mathrm{MnO}(0.02-0.18 \%$, mean $=0.09 \%)$ were determined for all samples (Table 2).

Table 2

Major and trace element concentrations of the samples

\begin{tabular}{|c|c|c|c|c|c|c|c|c|c|c|c|}
\hline \multirow{2}{*}{$\begin{array}{c}\text { Region } \\
\text { Area }\end{array}$} & \multicolumn{6}{|c|}{ Shamakhi-Gobustan } & \multicolumn{5}{|c|}{ Absheron } \\
\hline & $\begin{array}{l}\text { Boyuk } \\
\text { Siyaki }\end{array}$ & Jəngichay & Shikhzarli & Demirchi & $\begin{array}{l}\text { Bozaa- } \\
\text { khtarma }\end{array}$ & Qotur & $\begin{array}{l}\text { Otman- } \\
\text { bozdagh }\end{array}$ & Lokbatan & $\begin{array}{c}\text { Bozdagh- } \\
\text { Qobu }\end{array}$ & Keyraki & 疋 \\
\hline Sample & 1 & 2 & 3 & 4 & 5 & 6 & 7 & 8 & 9 & 10 & \\
\hline \multicolumn{12}{|c|}{ Major oxide $(\%)$} \\
\hline $\mathrm{SiO}_{2}$ & 46.04 & 49.55 & 53.39 & 55.55 & 51.23 & 46.43 & 49.71 & 46.07 & 54.39 & 45.72 & 49.81 \\
\hline $\mathrm{Al}_{2} \mathrm{O}_{3}$ & 13.36 & 15.36 & 16.06 & 16.81 & 14.93 & 12.69 & 15.10 & 12.96 & 15.27 & 13.82 & 14.64 \\
\hline $\mathrm{Fe}_{2} \mathrm{O}_{3}$ & 13.54 & 4.92 & 7.29 & 5.53 & 8.54 & 4.97 & 5.63 & 5.42 & 5.46 & 7.12 & 6.84 \\
\hline $\mathrm{FeO}$ & 12.18 & 4.43 & 6.56 & 4.98 & 7.68 & 4.47 & 5.07 & 4.88 & 4.91 & 6.41 & 6.16 \\
\hline $\mathrm{CaO}$ & 1.37 & 5.22 & 0.37 & 2.09 & 0.29 & 2.97 & 7.32 & 8.47 & 1.97 & 9.67 & 3.97 \\
\hline $\mathrm{Na}_{2} \mathrm{O}$ & 1.15 & 1.38 & 1.34 & 1.00 & 0.97 & 1.76 & 1.50 & 1.63 & 1.42 & 1.23 & 1.34 \\
\hline $\mathrm{K}_{2} \mathrm{O}$ & 2.06 & 3.84 & 3.65 & 3.61 & 3.61 & 2.93 & 3.47 & 3.38 & 3.89 & 3.15 & 3.36 \\
\hline $\mathrm{MgO}$ & 2.67 & 3.20 & 2.49 & 2.25 & 2.58 & 2.76 & 2.56 & 2.81 & 2.89 & 2.34 & 2.65 \\
\hline $\mathrm{TiO}_{2}$ & 0.74 & 0.75 & 0.76 & 0.87 & 0.71 & 0.61 & 0.83 & 0.66 & 0.80 & 0.90 & 0.76 \\
\hline $\mathrm{P}_{2} \mathrm{O}_{5}$ & 0.39 & 0.04 & 0.03 & 0.26 & 0.03 & 0.25 & 0.21 & 0.25 & 0.17 & 0.08 & 0.17 \\
\hline $\mathrm{SO}_{3}$ & 0.45 & 3.06 & 3.90 & 1.26 & 7.37 & 4.69 & 1.69 & 3.30 & 3.20 & 0.35 & 2.93 \\
\hline $\mathrm{MnO}$ & 0.18 & 0.07 & 0.09 & 0.02 & 0.02 & 0.05 & 0.13 & 0.07 & 0.07 & 0.17 & 0.09 \\
\hline \multicolumn{12}{|c|}{ Trace element (ppm) } \\
\hline $\mathrm{Ba}$ & 235 & 405 & 426 & 555 & 384 & 412 & 241 & 516 & 142 & 434 & 375 \\
\hline $\mathrm{Zr}$ & 116 & 196 & 215 & 142 & 184 & 214 & 117 & 419 & 317 & 154 & 207.4 \\
\hline $\mathrm{Br}$ & 8 & 12 & 5 & 1 & 5 & 72 & 5 & 5 & 8 & 3 & 12.4 \\
\hline Mo & 80 & 77 & 64 & 48 & 126 & 5 & 19 & 16 & 34 & 12 & 48.1 \\
\hline $\mathrm{Sr}$ & 116 & 325 & 214 & 317 & 134 & 294 & 295 & 426 & 1000 & 426 & 354.7 \\
\hline $\mathrm{Cu}$ & 49 & 11 & 11 & 83 & 94 & 88 & 19 & 89 & 12 & 15 & 47.1 \\
\hline $\mathrm{Cr}$ & 87 & 112 & 141 & 84 & 96 & 214 & 216 & 212 & 134 & 142 & 143.8 \\
\hline $\mathrm{Rb}$ & 53 & 218 & 191 & 94 & 175 & 184 & 710 & 114 & 41 & 81 & 186.1 \\
\hline $\mathrm{Zn}$ & 83 & 71 & 86 & 112 & 85 & 84 & 77 & 100 & 541 & 114 & 135.3 \\
\hline $\mathrm{Ni}$ & 74 & 16 & 102 & 31 & 75 & 34 & 41 & 176 & 60 & 74 & 68.3 \\
\hline $\mathrm{Se}$ & 0.4 & 0.1 & 0.6 & 0.3 & 11.6 & 0.7 & 0.3 & 0.5 & 0.1 & 0.4 & 1.5 \\
\hline As & 5 & 3 & 5 & 8 & 2 & 7 & 23 & 3 & 9 & 7 & 7.2 \\
\hline $\mathrm{Ga}$ & 17 & 8 & 15 & 11 & 7 & 12 & 14 & 5 & 8 & 12 & 10.9 \\
\hline $\mathrm{V}$ & 31 & 104 & 246 & 241 & 964 & 41 & 24 & 61 & 61 & 71 & 184.4 \\
\hline $\mathrm{U}$ & 3 & 1 & 2 & 1 & 1 & 1 & 1 & 1 & 3 & 1 & 1.5 \\
\hline $\mathrm{Pb}$ & 7 & 34 & 12 & 19 & 19 & 18 & 9 & 18 & 11 & 21 & 16.8 \\
\hline
\end{tabular}

The major oxides in the composition of samples were compared with average shale [47], NASC [25] and average black shale [49]. The $\mathrm{SiO}_{2}$ and $\mathrm{Al}_{2} \mathrm{O}_{3}$ values corresponds to the average shale, while the $\mathrm{Fe}_{2} \mathrm{O}_{3}$ value proper to NASC and the $\mathrm{CaO}$, $\mathrm{Na}_{2} \mathrm{O}, \mathrm{K}_{2} \mathrm{O}, \mathrm{MgO}, \mathrm{TiO}_{2}$. The $\mathrm{P}_{2} \mathrm{O}_{5}$ values coincide with both shales. Only for the $\mathrm{Al}_{2} \mathrm{O}_{3}$ value and alkaline compounds were established a correspondence compared with the average black shale (Table 3 ).

The major oxides in the samples were compared with the cognominal rocks of some countries that have extensive experience in the oil shale industry. The studied oil shale demonstrates similarity with the oil shale of the Estonian kukersite deposit [15] and Green River Formation of USA [45]. A associative similarity was recoded in the concentration of $\mathrm{SiO}_{2}, \mathrm{Al}_{2} \mathrm{O}_{3}$ and $\mathrm{CaO}$. The studied samples prevail on the oil shale of the Gurun basin of Turkey
[38], Baltic basin of Russia [28] and Sultani deposit of Jordan [8] on the mean $\mathrm{SiO}_{2}$ value. Referred to the $\mathrm{CaO}$ content, these three countries have a significant advantage (Table 4). High concentrations of $\mathrm{CaO}$ characterize a relationship with biochemical source, including cementing in the center of the ba$\sin [52]$. The $\mathrm{CaO}$ value is significantly higher in the samples taken from the mud volcanic areas in Absheron region (excluding Bozdagh-Qobu) than in Shamakhi- Gobustan region (excluding Jangichay) (Table 2). This factor may be related to a depositional environment, in which the samples formed; instabilities at the level of lake, lagoon, etc., as well as intensity of transport of dissolved chemical components.

Trace elements. The mean $\mathrm{Zr}$ value in oil shale is $207 \mathrm{ppm}$, and there is a coincidence for this trace element compared to NASC [25] and PAAS [46] 
Comparison of chemical composition of the studied shales with published averages

\begin{tabular}{|c|c|c|c|c|c|}
\hline & $\begin{array}{c}\text { Present } \\
\text { study }\end{array}$ & NASC [25] & $\begin{array}{c}\text { Average } \\
\text { shales [47] }\end{array}$ & $\begin{array}{c}\text { Average black } \\
\text { shales [49] }\end{array}$ & $\begin{array}{l}\text { Post-Archea } \\
\text { tralian Shal }\end{array}$ \\
\hline & \multicolumn{5}{|c|}{ Major element oxide (\%) } \\
\hline $\mathrm{SiO}_{2}$ & 45.81 & 64.82 & 58.50 & - & 62.80 \\
\hline $\mathrm{Al}_{2} \mathbf{O}_{3}$ & 14.64 & 17.05 & 15.00 & 13.00 & 18.90 \\
\hline $\mathrm{Fe}_{2} \mathrm{O}_{3}$ & 6.84 & 5.70 & 4.72 & 3.00 & 7.08 \\
\hline $\mathrm{CaO}$ & 3.97 & 3.51 & 3.10 & 2.10 & 1.30 \\
\hline $\mathrm{Na}_{2} \mathrm{O}$ & 1.34 & 1.13 & 1.30 & 0.90 & 1.20 \\
\hline $\mathrm{K}_{2} \mathrm{O}$ & 3.36 & 3.97 & 3.10 & 2.40 & 3.70 \\
\hline MgO & 2.65 & 2.83 & 2.50 & 1.20 & 2.20 \\
\hline $\mathrm{TiO}_{2}$ & 0.76 & 0.80 & 0.77 & 0.33 & 1.00 \\
\hline $\mathbf{P}_{2} \mathbf{O}_{5}$ & 0.17 & 0.15 & 0.16 & - & 0.16 \\
\hline MnO & 0.09 & - & - & 0.02 & 0.11 \\
\hline \multicolumn{6}{|c|}{ Trace element (ppm) } \\
\hline $\mathbf{S r}$ & 354.7 & 142 & 300 & 200 & 200 \\
\hline $\mathbf{B a}$ & 375 & 636 & 580 & 300 & 650 \\
\hline $\mathbf{V}$ & 184.4 & 130 & 130 & 150 & 150 \\
\hline $\mathbf{N i}$ & 68.3 & 58 & 68 & 50 & 55 \\
\hline $\mathrm{Cr}$ & 143.8 & 125 & 90 & 100 & 110 \\
\hline Zn & 135.3 & - & 95 & 300 & 85 \\
\hline $\mathbf{C u}$ & 47.1 & - & 45 & 70 & 50 \\
\hline $\mathrm{Zr}$ & 207.4 & 200 & 160 & - & 210 \\
\hline
\end{tabular}

Comparison of the major oxides of the studied samples and oil shale of some countries with published averages (\%)

$\begin{array}{lccc} & \begin{array}{c}\text { Present } \\ \text { study }\end{array} & \begin{array}{c}\text { Gurun } \\ \text { Basin (Tur- } \\ \text { key) [38] }\end{array} & \begin{array}{c}\text { Baltic basin } \\ \text { (Russia) } \\ {[\mathbf{2 8}]}\end{array} \\ \mathbf{S i O}_{2} & 49.80 & 16.13 & 33.22 \\ \mathbf{A l}_{2} \mathbf{O}_{3} & 14.64 & 4.67 & 7.69 \\ \mathbf{F}_{2} \mathbf{O}_{3} & 6.84 & 3.18 & 4.26 \\ \mathbf{T i O}_{2} & 0.76 & 0.24 & 1.32 \\ \mathbf{M g O} & 2.65 & 7.27 & 0.98 \\ \mathbf{C a O} & 3.97 & 29.42 & 39.95 \\ \mathbf{N a} \mathbf{O} & 1.33 & 1.58 & - \\ \mathbf{K}_{2} \mathbf{O} & 3.36 & 2.10 & 7.18 \\ \mathbf{P}_{\mathbf{2}} \mathbf{O}_{5} & 0.17 & 0.16 & 0.47 \\ \mathbf{M n O} & 0.09 & 0.01 & 0.11\end{array}$

(Table 3). This indication differs sharply from some of the world's oil shale deposits and basins, including the Hatildag deposit of Turkey (14 ppm) [44] and Sultan deposit in Jordan (46 ppm) [8]. The mean $\mathrm{Sr}$ and $\mathrm{Ni}$ values for the oil shale are 355 and $68 \mathrm{ppm}$ (Table 3). Relatively, the Sr content in average shale is $300 \mathrm{ppm}$ [47], which roughly corresponds to oil shale in the present study (Table 3). However, the values of the same trace element in the NASC [25], average black shale [49] and PAAS [46] considerably less $(142,200$ and $200 \mathrm{ppm})$ (Table 3). The mean $\mathrm{Sr}$ value is $430 \mathrm{ppm}$ in the Hatildag oil shale deposit [44], Sultani - 707 ppm [8].

$\begin{array}{ccc}\begin{array}{c}\text { Sultani deposit } \\ \text { (Jordan) }\end{array} & \begin{array}{c}\text { Estonia depos- } \\ \text { it (Estonia) }\end{array} & \begin{array}{c}\text { Green } \\ \text { River formation } \\ \text { (USA) [45] }\end{array} \\ 26.26 & {[\mathbf{1 5 ]}} & 53.71 \\ 2.87 & 59.80 & 13.53 \\ 1.12 & 16.10 & 5.40 \\ 0.13 & 2.80 & 0.58 \\ 0.95 & 0.70 & 6.08 \\ 26.3 & 0.40 & 5.47 \\ 0.27 & 0.70 & 2.37 \\ 1.37 & 0.80 & 1.26 \\ 3.48 & 6.30 & 0.20 \\ - & - & 0.05\end{array}$

High $\mathrm{Sr}$ value in sedimentary rocks is associated with nano-calcareous planktons [32] and also aragonite sources. The mean $\mathrm{Ni}$ value is distributed in approximate concentrations in the noted shales (Table 3). However, the content of this trace element in the oil shale of the Hatildag deposit is 103 ppm [44], Sultani - 139 ppm [8], Baltic basin -10 ppm [30], Kukersit of Estonia - 17 ppm [48] and Green River - 1-10 ppm [17]. The origin of $\mathrm{Ni}$ in the studied oil shale is most likely associated with organic sources. The $\mathrm{Zn}$ and $\mathrm{Cu}$ values in oil shale are 135 and 47 ppm (Table 3). The $\mathrm{Zn}$ value is relatively high in the average shale and in PAAS (95 and 85 ppm) (Table 
3). The mean $\mathrm{Zn}$ value for average black shale is $300 \mathrm{ppm}$. The average $\mathrm{Zn}$ value in the oil shale deposit in Turkey is $15 \mathrm{ppm}$ [44], Sultani - $649 \mathrm{ppm}$ [8], Baltic basin - 75 ppm [30], Kukersit deposit $49 \mathrm{ppm}$ [48] and Green River formation - $10 \mathrm{ppm}$ [17]. The mean value of $\mathrm{Cu}$ does not differ much from the average shale and PAAS (45 and $50 \mathrm{ppm}$ ). In black average shale, the value of this trace element is slightly greater, $70 \mathrm{ppm}$ (Table 3 ). The average $\mathrm{Cu}$ value of the Hatildag deposit is $38 \mathrm{ppm}$ [44], Sultani - 115 ppm [8] and Baltic basin - 10 ppm [30].
Geochemical classifications and maturity. Based on the chemical classification diagram of log $\left(\mathrm{Fe}_{2} \mathrm{O}_{3} / \mathrm{K}_{2} \mathrm{O}\right)$ versus $\log \left(\mathrm{SiO}_{2} / \mathrm{Al}_{2} \mathrm{O}_{3}\right)$ [27], it was determined that most of samples correspond to shale, and only one sample with a rich $\mathrm{Fe}_{2} \mathrm{O}_{3}$ content correlate with Fe-shale (Table 2, Fig. 3). Shale is clastic sedimentary rock consisted of clay minerals, as well as quartz and calcite. The biological, chemical and coastal-mechanical erosions, as well as the shelf, lagoon, deep but relatively stagnant water environments, are characteristic for its genesis.

A ratio $\mathrm{K}_{2} \mathrm{O} / \mathrm{Al}_{2} \mathrm{O}_{3}$ differs sharply in clay min-

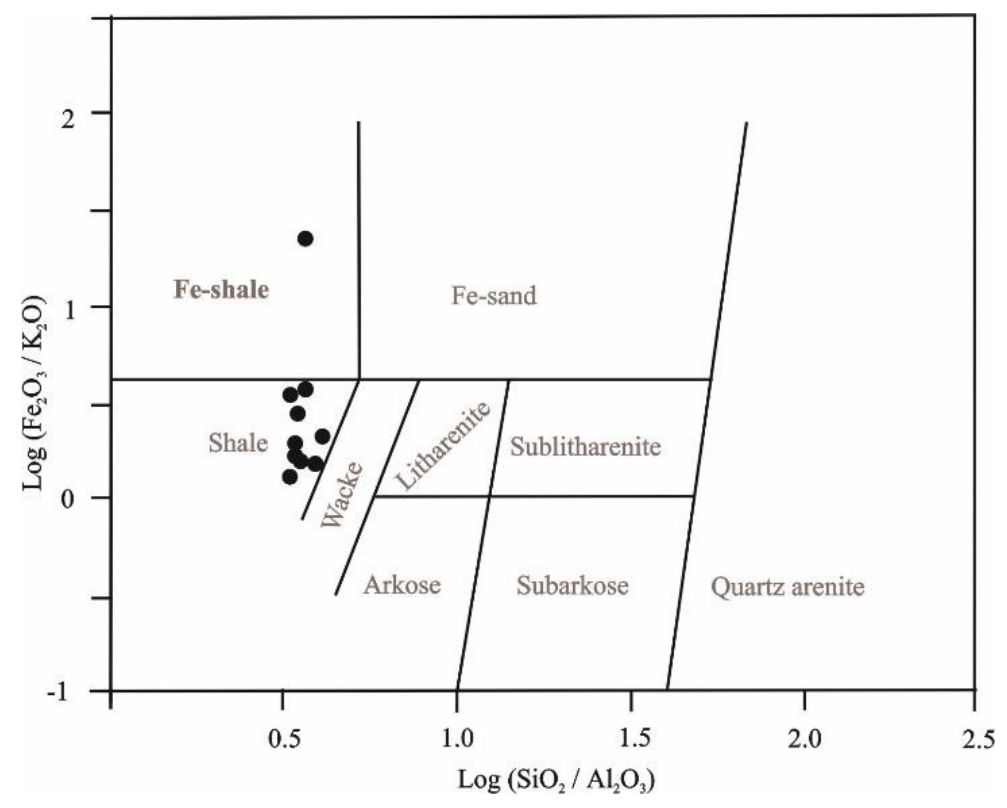

Fig. 3. $\mathrm{Log}\left(\mathrm{Fe}_{2} \mathrm{O}_{3} / \mathrm{K}_{2} \mathrm{O}\right)$ versus $\log \left(\mathrm{SiO}_{2} / \mathrm{Al}_{2} \mathrm{O}_{3}\right)$ classification diagram

[27] for the selected oil shale samples

erals and feldspar. The ratio value forms an idea of the original composition of sedimentary rocks. $\mathrm{K}_{2} \mathrm{O} / \mathrm{Al}_{2} \mathrm{O}_{3}$ ratio was established for clay minerals 0 $0.3 \%$, but for feldspar 0.3-0.9\%. $\mathrm{K}_{2} \mathrm{O} / \mathrm{Al}_{2} \mathrm{O}_{3}>0.5$ indicates the content of alkaline feldspar associated with other minerals. The ratio varies from 0.15 to 0.26 for the studied oil shale (mean $=0.23$ ). This result indicates the absolute superiority of clay minerals over K-containing minerals, including $\mathrm{K}$ feldspar and micas.

Higher $\mathrm{Na}_{2} \mathrm{O} / \mathrm{Ka}_{2} \mathrm{O}$ values indicate a bond with plagioclase. Relatively low values characterize change in extracellular cations of clay minerals. This feature provides an association between sodium and illite. The determined ratio for samples varries from 0.27 to 0.60 (mean $=0.41$ ), corresponds to a low degree of maturity. A result of the correlation between $\mathrm{Na}_{2} \mathrm{O}$ and $\mathrm{Al}_{2} \mathrm{O}_{3}$ is negative $(\mathrm{r}=-0.37)$, which can be explained by the fact that sodium does not bind to plagioclase in the samples, and the main bond is associated with illite. The $\mathrm{K}_{2} \mathrm{O} / \mathrm{Na}_{2} \mathrm{O}$ ratio is 1.66-3.72 $($ mean $=2.56)$, which is characteristic for K-bearing minerals.
$\mathrm{Al}_{2} \mathrm{O}_{3} /\left(\mathrm{CaO}+\mathrm{MgO}+\mathrm{Na}_{2} \mathrm{O}+\mathrm{K}_{2} \mathrm{O}\right)$ ratio indicates the mobility of major oxides that form rocks [24]. The oxides present in the content of samples are unstable since the determined values of this ratio are lower (0.80-2.05).

The ratios of $\mathrm{SiO}_{2} / \mathrm{Al}_{2} \mathrm{O}_{3}$ and $\mathrm{Fe}_{2} \mathrm{O}_{3} / \mathrm{K}_{2} \mathrm{O}$ are very informative as an indicator of mineralogical stability in sedimentary rocks. Lower $\mathrm{SiO}_{2} / \mathrm{Al}_{2} \mathrm{O}_{3}$ and higher $\mathrm{Fe}_{2} \mathrm{O}_{3} / \mathrm{K}_{2} \mathrm{O}$ values are considered mineralogically less stable and more prone to reactivity under supercritical $\mathrm{CO} 2$ exposure $[20 ; 39]$. The ratio of $\mathrm{SiO}_{2} / \mathrm{Al}_{2} \mathrm{O}_{3}$ is lower than that of $\mathrm{Fe}_{2} \mathrm{O}_{3} / \mathrm{K}_{2} \mathrm{O}$, and this result leads to the fact that the studied samples are classified as mineralogically unstable.

A ratio of $\mathrm{SiO}_{2} / \mathrm{Al}_{2} \mathrm{O}_{3}$ is used to determine the maturity properties of sedimentary rocks, as well as to assess the presence of quartz associated with clay minerals or feldspar $[16 ; 19]$. In this regard, high ratios characterize mineralogical mature (quartzose, rounded) and while low ratios represent chemically immature rocks [40]. Since the sizes of fine-grained rocks have a positive effect on maturity, but rocks, mainly consist of clay minerals, have a negative im- 
pact on this feature. Thus, maturity can be recorded in rocks, which rich with quartz, fine-grained sands, and feldspar. If the $\mathrm{SiO}_{2} / \mathrm{Al}_{2} \mathrm{O}_{3}$ ratio is characterized by high values, up to 5 , it indicates progressive maturity for quartz and feldspar. The value of this ratio for present study range from 3.22 to 3.66 , the mean value is 3.4. Such values point to the superiority of clay minerals in the studied rocks. The $\mathrm{Al}_{2} \mathrm{O}_{3}, \mathrm{Fe}_{2} \mathrm{O}_{3}$ and $\mathrm{TiO}_{2}$ values for the composition of samples shows a tendency like $\mathrm{Al}_{2} \mathrm{O}_{3}>\mathrm{Fe}_{2} \mathrm{O}_{3}>\mathrm{TiO}_{2}$ (Table 2 ). The obtained result corresponds to clay minerals [37]. A positive result of the correlation between $\mathrm{TiO}_{2}$ and $\mathrm{Al}_{2} \mathrm{O}_{3}(\mathrm{r}=0.57)$ also confirms this conclusion.

Unstable and recrystallization features of clay minerals lead to acute mineralogical changes during diagenesis and low-temperature metamorphism [50]. Isochemical features for such processes is characteristic. Index of Compositional Variability (ICV), which indicates a richness of alumina relative to the cations of some major oxides in rocks, is determined by the formula [ICV $=\left(\mathrm{Fe}_{2} \mathrm{O}_{3}+\mathrm{K}_{2} \mathrm{O}+\right.$ $\left.\left.\mathrm{Na}_{2} \mathrm{O}+\mathrm{CaO}+\mathrm{MgO}+\mathrm{MnO}+\mathrm{TiO}_{2}\right) / \mathrm{Al}_{2} \mathrm{O}_{3}(\%)\right]$ [18]. The index also allows detecting detrital mineralogical properties of rocks. The calculated ICV value for samples is 0.91-1.78 (mean $=1.32)$. Since rocks characterized by low ICV values are associated with the cratonic envoriments and clay minerals. Most of the samples have a higher value than 1, indicating the presence of fewer clay minerals and more rock-forming minerals, such as plagioclase, alkali-feldspar, etc.

Palaeoweathering. Intensity of chemical weathering is directly related to a number of factors, such as the composition of the parent rock, climatic condition, the duration of weathering, the degree of uplift tectonic movement, etc. The chemical weathering has a certain effect on the composition of silicate rocks. This is characterized by more stable properties of large cations $(\mathrm{Ba}, \mathrm{Rb}$, etc.) compared to small ones $(\mathrm{Na}, \mathrm{Ca}$, etc.) in weathered residues [34]. During weathering, an element with a smaller ionic radius is separated from feldspar and the abundance of such an element compared to a stable element in the content of rocks indicates the degree of chemical weathering. A comparison of arid and humid conditions indicates that arid is characterized by relatively poor chemical weathering. A climatic condition accompanied by heavy rainfall leads to the loss of unstable minerals. In addition, $\mathrm{CO}_{2}$ in the atmosphere and temperature condition has a positive effect on the intensity of weathering. Thus, the high temperature increases the decomposition of plagioclase and potassium feldspars, as well as hydrolysis. The lack of plants, the intensification of temperature and rainfall can lead to strong weathering.
Some methods are used for the determination of weathering based on the abundance of mobile or immobile major oxides in the rock. Chemical Index of Alteration ((CIA), [35]) is an index indicates of the conversion of plagioclase and potassium feldspar into clay minerals. The computational formula of the coefficient is: CIA $=100 \times\left[\mathrm{Al}_{2} \mathrm{O}_{3} /\left(\mathrm{Al}_{2} \mathrm{O}_{3}+\right.\right.$ $\left.\mathrm{CaO}^{*}+\mathrm{Na}_{2} \mathrm{O}+\mathrm{K}_{2} \mathrm{O}\right)$ ]. A value of $\mathrm{CaO}^{*}$ indicates only $\mathrm{CaO}$ in silicates. Since this value is different from $\mathrm{CaO}$, the following formula $\left[\mathrm{CaO}^{*}=\mathrm{CaO}-\right.$ calcite - dolomite - apatite] was used for the index calculation. The calculation of the index was performed within the molar proportions of the oxides. For the studied rocks, the CIA values are between 72 and 80 (the mean value is 75), which indicate moderate to high degree of weathering. CIA versus $\mathrm{Al} / \mathrm{Na}$ plot for the samples is almost identical to the PAAS (Fig. 4). Such a trend characterizes $\mathrm{N}^{+}$diagenetic loss.

According to the ICV-CIA plot, the samples were subjected to intensive weathering in the source area and only after the post-sedimentation processes; there were changes in their composition (Fig. 5). $\mathrm{Up}$ to 50 CIA values indicate unchanged plagioclase, as well as $\mathrm{K}$-feldspar. The minimum values of CIA for all samples $>70$. Since CIA values approach 100 indicate the conversion of feldspar to clay minerals, such as gibbsite, kaolinite [21]. The CIA values and silicate clay minerals in the shale samples (Table 1) also confirm moderate to high degree of weathering. The obtained values may be related either of the original sources or during transport before deposition and may reflect lowrelief and arid climatic state in the source area [51].

The results of the ternary diagram of $\mathrm{Al}_{2} \mathrm{O}_{3}$, $\mathrm{CaO}^{*}+\mathrm{Na}_{2} \mathrm{O}$ and $\mathrm{K}_{2} \mathrm{O}(\mathrm{A}-\mathrm{CN}-\mathrm{K})$ [36] was used to determine the chemical weathering properties, show that all the samples plot parallel to the $\mathrm{A}-\mathrm{CN}$ join. The normal weathering tendency is focused toward illite, but in general, the effect of K-metasomatism is not excluded. The obtained result supports a conclusion that the protolith of oil shales coincides with mafic and intermediate types of igneous rocks (Fig. 6).

The plot based on the amount of $\mathrm{Al}_{2} \mathrm{O}_{3}$ and $\mathrm{K}_{2} \mathrm{O}$ of samples indicates a relationship with illite (Fig. 7). Such a conclusion is most likely based on the conversion of $\mathrm{K}$-feldspar and muscovite into clay minerals as a result of weathering in ar$\mathrm{id} /$ semiarid climatic conditions. In addition, the relationship between potassium and illite is confirmed by the result of correlation $\mathrm{Ka}_{2} \mathrm{O}$ versus $\mathrm{Al}_{2} \mathrm{O}_{3}(\mathrm{r}=$ $0.65)$.

Conclusions. 11 minerals belonging to 5 classes were determined in the samples which silicates predominate. 


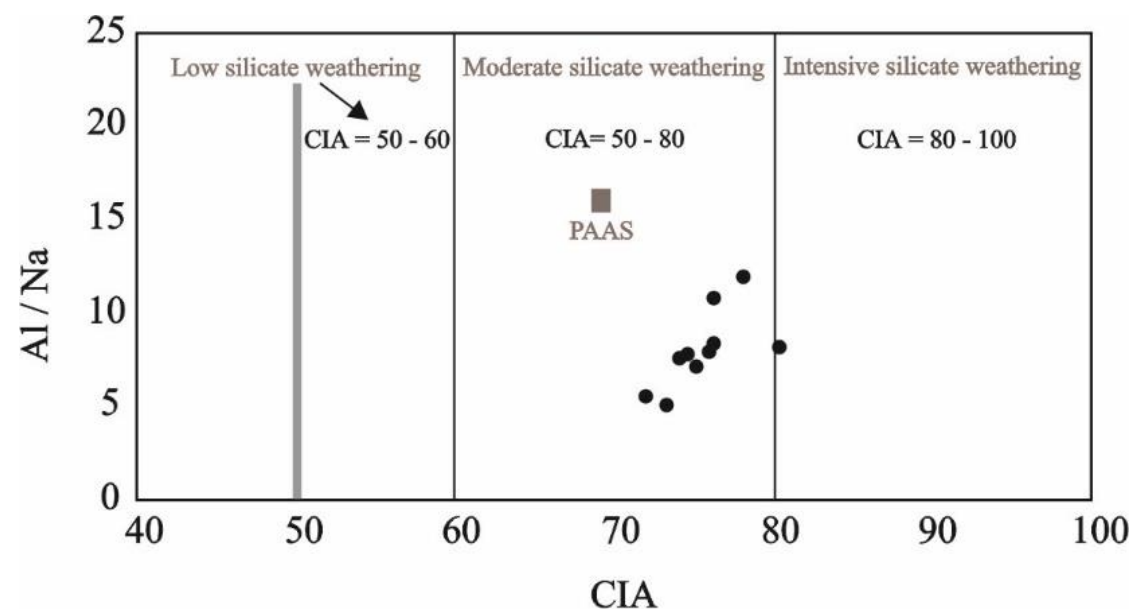

Fig. 4. Scatter plot of CIA versus Al / Na ratio [43] for the studied samples. PAAS range from [46]

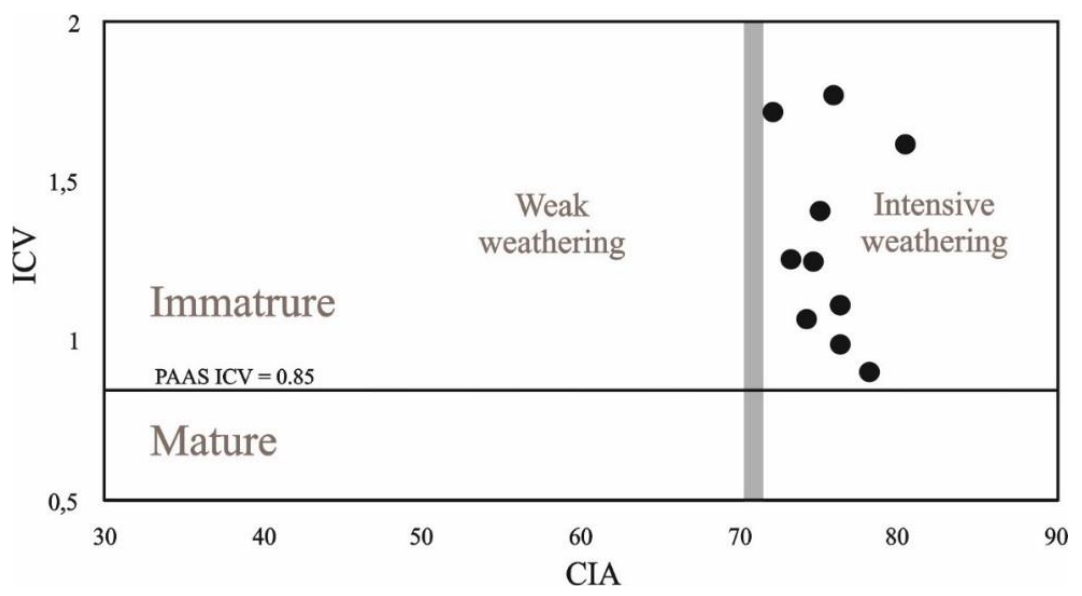

Fig. 5. CIA-ICV plot [31] for the samples. PAAS range from [46]

(A)

$\mathrm{Al}_{2} \mathrm{O}_{3}$

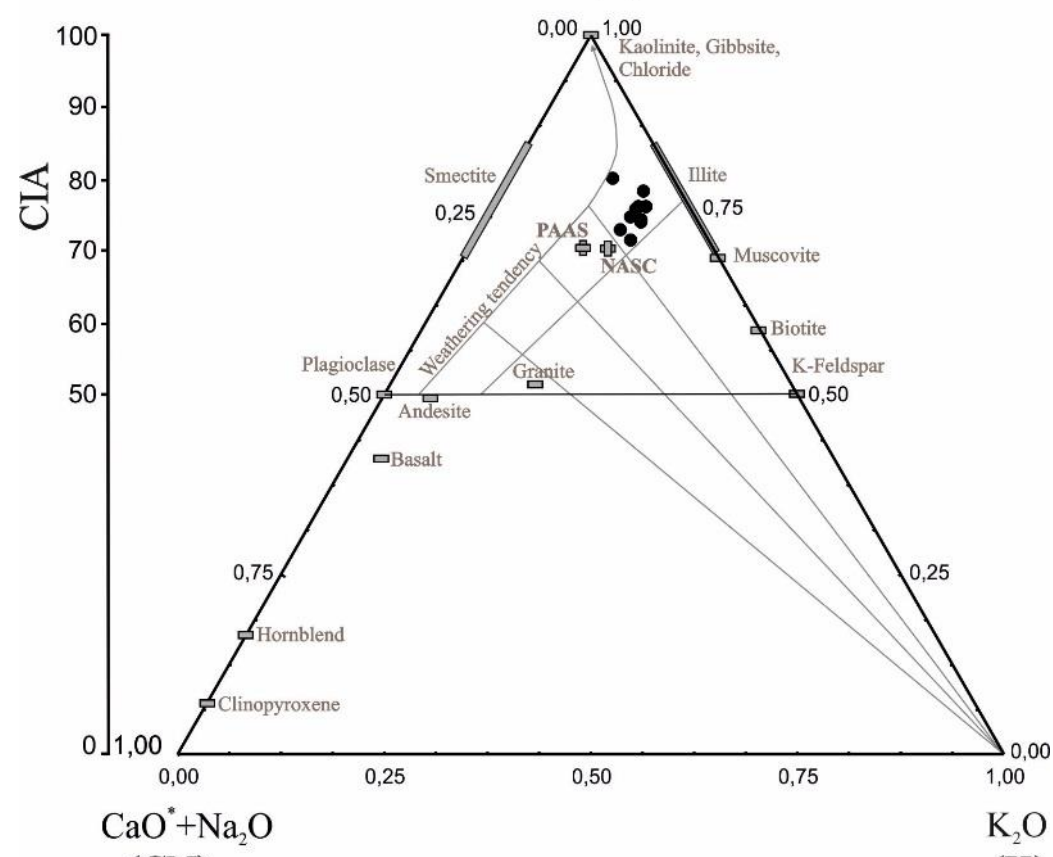

$(\mathrm{CN})$

(K)

Fig. 6. A-CN-K ternary diagram [36] of molecular proportions of $\mathrm{Al}_{2} \mathrm{O}_{3}-\left(\mathrm{CaO}^{*}+\mathrm{Na}_{2} \mathrm{O}\right)-\mathrm{K}_{2} \mathrm{O}$ for the oil shale samples. PAAS range from [46] and NASC [25] 


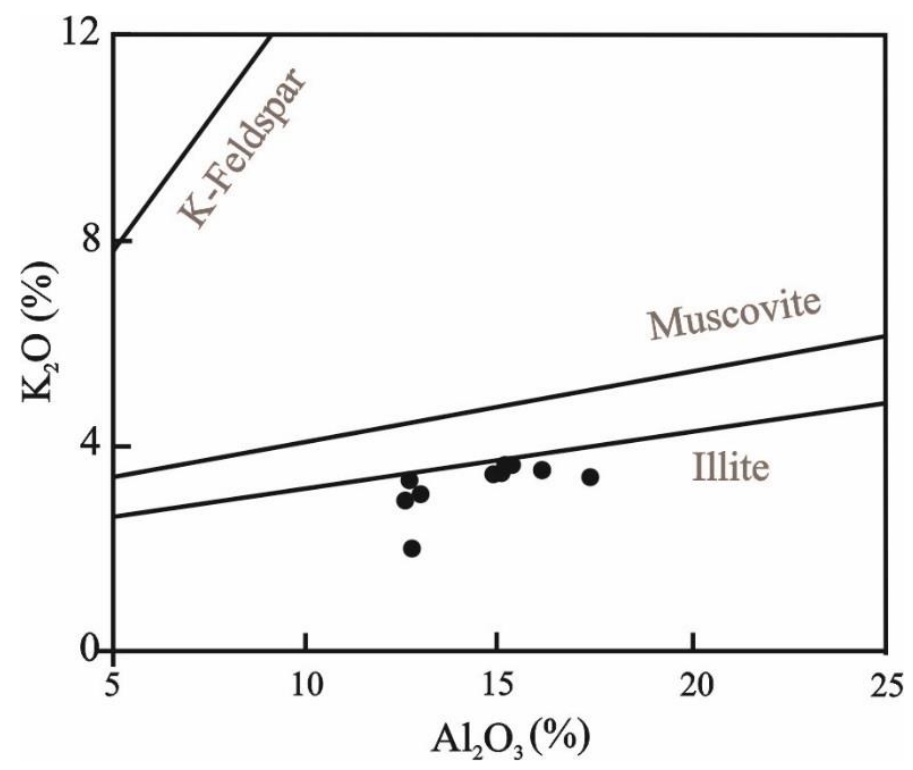

Fig. 7. $\mathrm{Al}_{2} \mathrm{O}_{3}$ versus $\mathrm{K}_{2} \mathrm{O}$ plot [18] of oil shale samples

The coincidence between samples and shale was established using the classification plot based on $\log \left(\mathrm{SiO}_{2} / \mathrm{Al}_{2} \mathrm{O}_{3}\right)$ versus $\log \left(\mathrm{Fe}_{2} \mathrm{O}_{3} / \mathrm{K}_{2} \mathrm{O}\right)$.

The $\mathrm{K} 2 \mathrm{O} / \mathrm{A} 12 \mathrm{O} 3$ ratio confirms a superiority of clay minerals in the composition of oil shale compared to K-minerals, including K-feldspar. The estimates based on the $\mathrm{Al}_{2} \mathrm{O}_{3} /\left(\mathrm{CaO}+\mathrm{MgO}+\mathrm{Na}_{2} \mathrm{O}+\right.$ $\mathrm{K}_{2} \mathrm{O}$ ) and $\mathrm{Fe}_{2} \mathrm{O}_{3} / \mathrm{K}_{2} \mathrm{O}, \mathrm{SiO}_{2} / \mathrm{Al}_{2} \mathrm{O}_{3}$ ratios confirm the instability of oxides and minerals in the composition of samples. In addition, the ratios of $\mathrm{SiO}_{2} / \mathrm{Al}_{2} \mathrm{O}_{3}$ and $\mathrm{Al}_{2} \mathrm{O}_{3}>\mathrm{Fe}_{2} \mathrm{O}_{3}>\mathrm{TiO}_{2}$ support an idea that the samples are immature and associated with clay minerals.
The values of the CIA, and the plots for CIA versus ICV, CIA versus $\mathrm{Al} / \mathrm{Na}$ ratio and the ternary diagram $\mathrm{A}-\mathrm{CN}-\mathrm{K}$, as well as the study related to major oxide confirm moderate to high degree of weathering. The result of $\mathrm{A}-\mathrm{CN}-\mathrm{K}$ ternary diagram support that the weathering tendency of the samples plots close to the illite. The effect of $\mathrm{K}$ metasomatism in this process is also not excluded. The role of post-sedimentation processes were most likely involved in the conversion. The protolith of oil shale samples is associated with mafic and intermediate igneous sources.

\section{References}

1. Abbasov, O. R. Distribution regularities of shales of Paleogene-Miocene sediments in Gobustan : abstract of PhD thesis ... on PhD in Earth Sciences : 26.11.09 / O. R. Abbasov [Institute of Geology and Geophysics, Azerbaijan National Academy of Sciences] - Baku, 2009. - 24 p.

2. Abbasov, O. R. Some new data of geochemical researches of combustible slates of Azerbaijan / O. R. Abbasov, A. N. Mamedova [et al.] // Geology, Geophysics and Development of Oil and Gas Fields. - 2013. - Is. 2, - P. 32-35.

3. Abbasov, Orhan. Oil shale of Azerbaijan: geology, geochemistry and probable reserves / Orhan Abbasov // International Journal of Research Studies in Science, Engineering and Technology. - 2015. - Vol. 2, Is. 9. - P. 31-37.

4. Abbasov, Orhan. Organic compounds in ejected rocks of mud volcanoes as geological and geochemical indicators of source rock: a study of oil shale in Shamakhi-Gobustan region (Azerbaijan) / Orhan Abbasov // International Journal of Current Advanced Research, - 2016. - Vol. 5, Is. 7. - P. 1042-1046.

5. Abbasov, O. R. Distribution regularities of oil shale in Azerbaijan / O. R. Abbasov // ISJ Theoretical \& Applied Science. - 2016. - Vol. 35, Is. 3. - P. 165-171. http://dx.doi.org/10.15863/TAS.2016.03.35.28.

6. Abbasov, O. R. Distribution regularities and geochemistry of oil shales in Azerbaijan / O. R. Abbasov // Mineral resources of Ukraine. - 2017. - Is. 2. - P. 22-30.

7. Aghayev, Aghamehdi. Geochemistry of sedimentation processes / Aghamehdi Agayev - Baku : Publishing house "Adiloghlu”, 2006. - 136 p.

8. Alali, Jamal. Oil Shale in Jordan / Jamal Alali, Abu Salah, Abdelfattah, Yasin Suha M., Al Omari Wasfi - Natural Resources Authority of Jordan, - 2015. - 26 p.

9. Aliyev, Ad. A. Oil shales of Miocene in Azerbaijan / Ad. A. Aliyev, I. S. Belov, G. A. Aliyev // Azerbaijan Oil Industry. 2000. - Is. 5. - P. 7-11.

10. Aliyev, Ad. A. Oil shale of Paleogene-Miocene in Azerbaijan / Ad. A. Aliyev, I. S. Belov, T. A. Bayramov // Geologist of Azerbaijan. Scientific Bulletin. - 2003, - Is. 8. - P. 68-80.

11. Atlas of mud volcanoes in the world: Ad. A. Aliyev, I. S. Guliyev, F. G. Dadashev, R. R. Rahmanov. - Baku : Publishing house "Nafta-Press", "Sandro Teti Editore", 2015. - 361 p. 
12. Aliyev, Ad. A. Organic-geochemical study of oil shales in Pre-Caspian-Guba region (Azerbaijan) / Ad. A. Aliyev, O. R. Abbasov [et al.] // Mineral resources of Ukraine. - 2018. - Is. 3. $\quad-\quad$ P. $13-18$. https://doi.org/10.31996/mru.2018.3.13-18.

13. Organic geochemical characteristics of oil shale in Azerbaijan [Aliyev, Adil, Abbasov, Orhan] : The 36 $6^{\text {th }}$ National and the $3^{\text {rd }}$ International Geosciences Congress, February 25-27, 2018. - Tehran : 2018. - P. 1-10.

14. Aliyev, Ad. A. Genesis and organic geochemical characteristics of oil shale in Eastern Azerbaijan / Ad. A. Aliyev, O. R. Abbasov [et al.] // SOCAR Proceedings. - 2018. - Is. 3. - P. 4-15. http://dx.doi.org/10.5510/OGP20180300356.

15. Arro, H. Calculation of composition of Estonian oil shale and its combustion products on the basis of heating value / H. Arro, A. Prikk, T. Pihu // Oil Shale, - 1998. -Vol. 15, Is. 4. - P. 329-340.

16. Cingolani, C. A. Composition, provenance, and tectonic setting of Ordovician siliciclastic rocks in the San Rafael block: Southern extension of the Precordillera crustal fragment, Argentina / C. A. Cingolani, M. Manassero, P. Abre // Journal of South American Earth Sciences. - 2003. - Vol. 16, Is. 1. - P. 91-106. https://doi.org/10.1016/S08959811(03)00021-X.

17. Connie L. Wilkerson. Trace metal composition of Green River retorted shale oil / Wilkerson Connie L. // Fuel. 1982. - Vol. 61, Is. 1. - P. 63-70. https://doi.org/10.1016/0016-2361(82)90294-0.

18. Cox, $R$. The influence of sediment recycling and basement composition of evolution of mudrock chemistry in the Southwestern United States / R. Cox, D. R. Lowe, R. L. Cullers // Geochimica et Cosmochimica Acta. - 1995. - Is. 59. - P. 2919-2940. http://dx.doi.org/10.1016/0016-7037(95)00185-9.

19. Cullers, R. L. The geochemistry of shales, siltstones and sandstones of Pennsylvanian-Permian age, Colorado, USA: implications for provenance and metamorphic studies / R. L. Cullers // Lithos. - 2000. - Is. 51, - P. 181-203. https://doi.org/10.1016/S0024-4937(99)00063-8.

20. Farquhar, $\mathrm{S}$. M. A fresh approach to investigating $\mathrm{CO}_{2}$ storage: experimental $\mathrm{CO}_{2}$-water-rock interactions in a lowsalinity reservoir system / S. M. Farquhar, J. K. Pearce [et al.] // Chemical Geology, - 2014. - P. 1-70. https://doi.org/10.1016/j.chemgeo.2014.10.00.

21. Fedo, C. M. Unraveling the effects of potassium metasomatism in sedimentary rocks and paleosols, with implications for weathering conditions and provenance / C. M. Fedo, H. W. Nesbitt, G. M. Young // Geology. - 1995. - Is. 23. - P. 921-924. https://doi.org/10.1130/0091-7613(1995)023<0921:UTEOPM>2.3.CO;2

22. Geology of Azerbaijan /Ad. A. Aliyev, Ch. S. Aliyev, A. A. Feyzullayev, et al. ; editor Academician Ak. A. Ali-zadeh. - II Volume. - Baku : Publishing house "Elm”, 2015. - 341 p.

23. Gharrabi, M., The transformation of illite to muscovite in pelitic rocks: Constraints from X-ray diffraction / M. Gharrabi, B. Velde, J. -P. Sagon // Clays and Clay Minerals. - 1998. - Is. 46. - P. 79-88.

24. Gill, S. Implications of a lower Pennsylvanian Ultisol for equatorial Pangean climates and early, oligotrophic, forest ecosystems / S. Gill, K. Yemane // Geology, - 1996. - Vol. 24. Is. 10. - P. 905-908. https://doi.org/10.1130/00917613(1996)024<0905:IOALPU>2.3.CO;2.

25. Gromet, L. P. The "North American shale composite" its compilation, major, and trace elements characteristics / L. P. Gromet, R. F. Dymek [et al.] // Geochimica et Cosmochimica Acta. - 1984. - Is. 48, - P. $2469-2482$. https://doi.org/10.1016/0016-7037(84)90298-9.

26. Hawkins, P. J. Relationship between diagenesis, porosity reduction and oil replacement in Late Carbonifereous sandstone reservoirs, Bothamsall oil field, E. Midlands / P. J. Hawkins // Jour. Geol. Soc. London. - 1978. - Is. 135. - P. 7-24. https://doi.org/10.1144/gsjgs.135.1.0007.

27. Herron, M. M. Geochemical classification of terrigenous sands and shales from core and log data / M. M. Herron // Journal of Sedimentary Petrology. - 1988. - Is. 58. - P. 820-829.

28. Kondrasheva, N. K. Assessment of the possibility of using oil shale and shale-ash waste in industry / N. K. Kondrasheva // Notes of the Mining Institute. - 2016. - Is. 220. - P. 595-600.

29. Kortenski, J. Trace and major elements content and distribution in Neogene lignite from the Sofia Basin, Bulgaria / J. Kortenski, A. Sotirov // International Journal of Coal Geology. - 2002. - Is. 52. - P. 63-82.

30. Kler, V. R. Metallogeny and geochemistry of coal bearing and shale bearing strata of the USSR: regularities of elements concentration and study methods) /V. R. Kler, G. A. Volkova [et al.] - Moscow : Nauka, 1988. - 256 p.

31. Long, X. Geochemistry and Nd isotopic composition of the Early Paleozoic flysch sequence in the Chinese Altai, Central Asia: Evidence for a northward-derived mafic source and insight into Nd model ages in accretionary orogeny / X. Long, C. Yuan, [et al.] // Gondwana Research, - 2012. - Is. 22. - P. 554-566. https://doi.org/10.1016/j.gr.2011.04.009.

32. Martin, J. H. The Elemental Composition of Plankton / J. H. Martin, G. A. Knauer // Geochimica et Cosmochimica Acta. - 1973. - Is. 37. - P. 1639-1653. https://doi.org/10.1016/0016-7037(73)90154-3.

33. Nelson, Stephen A. Tectosilicates, carbonates, oxides, \& accessory minerals / Stephen A. Nelson. - New Orleans : Tulane University, 2004. - 15 p.

34. Nesbitt, H. W. Chemical processes affecting alkalis and alkaline earths during continental weathering / H. W. Nesbitt, G. Markovics, R. C. Price // Geochimica et Cosmochimica Acta. - 1980. - Is. 44. - P. 1659-1666. https://doi.org/10.1016/0016-7037(80)90218-5.

35. Nesbitt, H. W. Early Proterozoic climates and plate motion inferred from major element chemistry of Lutites / H. W. Nesbitt, G. M. Young // Nature. - 1982. - Is. 299. - P. 715-717. 
36. Nesbitt, H. W. Prediction of some weathering trends of plutonic and volcanic rocks based on thermodynamic and kinetic considerations / H. W. Nesbitt, G. M. Young // Geochimica et Cosmochimica Acta. - 1984. - Is. 48. - P. 1523-1534. https://doi.org/10.1016/0016-7037(84)90408-3.

37. Obasi, $R$. A. Use of geochemistry to study the provenance, tectonic setting, source-area weathering and maturity of Igarra Marble, Southwest, Nigeria / R. A. Obasi, H. Y. Madukwe // American Journal of Engineering Research. 2016. - Vol. 5, Is. 6, - P. 90-99.

38. Onal M. Stratigraphic, mineralogic and geochemical characterization of Gurun oil shales, central Anatolia, Turkey / M. Onal, T. Ayyildiz [et al.] // Oil Shale, - 2006. - Vol. 23, Is. 4. - P. 297-312.

39. Pettijohn, F. J. : Sand and Sandstone / F. J. Pettijohn, P. E. Potter, R. Siever ; - Berlin : Springer, $1987 .-213$ p.

40. Potter, P. E. Petrology and chemistry of modern big river sands / Potter, P. E. // The Journal of Geology. - 1978. Vol. 86, Is. 4. - P. 423-449.

41. Reserves of oil shale and natural bitumen : Map (Scale 1:1000000) / Ad. A. Aliyev, A. A. Bayramov, O. R. Abbasov, A. N. Mammadova . - Baku : National Atlas of the Republic of Azerbaijan, 2014 . - P. 101.

42. Rodrigo, D. L. The role of depositional setting and diagenesis on the reservoir quality of Devonian sandstones from the Solimones Basin, Brazilian Amazonia / D. L. Rodrigo, F. D. R. Luiz // Marine and Petroleum Geology. - 2002. Is. 19. - P. 1047-1071.

43. Servaraj, K. Moderate chemical weathering of subtropical Taiwan: constraints fromsolid-phase geochemistry of sediments and sedimentary rocks / K. Servaraj, C. C. Arthur // Journal of Geology. - 2006. - Is. 114. - P. $101-116$.

44. Shener, M. Geological, mineralogical and geochemical characteristics of oil shale bearing deposits in the Hatildag oil shale field, Goynuk, Turkey / M. Shener, I. Shenguler // Fuel. - 1998. - Is. 8. - P. 871-880.

45. Tank, R. W. Clay minerals of the Green River Formation (Eocene) of Wyoming / R. W. Tank // Clay Minerals. - 1972. - Is. 9. - P. 297-308.

46. Taylor, S. R. The continental crust: its composition and evolution / S. R. Taylor, S. M. McLennan. - Oxford: Blackwell, 1985. - 312 p. https://doi.org/10.1002/gj.3350210116.

47. Turekian, K. K. Distribution of the Elements in some major units of the Earth's crust / K. K. Turekian, K. H. Wedepohl // Geological Society of America, Bulletin. - 1961. - Is. 72. - P. 175-192.

48. Urov, K. Characteristics of oil shales and shale-like rocks of known deposits and outcrops / K. Urov, A. Sumberg // Oil shale. - 1999. - Vol. 16, Is. 3. - P. 1-64.

49. Vine, J. D. Geochemistry of black shale deposits / J. D. Vine, E. B. Tourtelot // Economic Geology and the Bulletin of the Society of Economic Geologists. - 1970. - Is. 65. - P. 253-272. https://doi.org/10.2113/gsecongeo.65.3.253.

50. Weaver, C. E. Clay water diagenesis during burial: how mud becomes gneiss / C. E. Weaver, K. C. Beck, C. O. Pollard // Special Papers - Geological Society of America. - 1971. - Is. 134. - P. 1-78.

51. Zaid, Samir Mahmoud. Provenance, diagenesis, tectonic setting, and geochemistry of Hawkesbury Sandstone (Middle Triassic), southern Sydney Basin, Australia / Samir Mahmoud Zaid, Fahad AL Gahtani // Turkish Journal of Earth Sciences. - 2015. - Is. 24. - P. 72-98. https://doi.org/10.3906/yer-1407-5.

52. Zaid, Samir Mahmoud. Geochemistry of shales from the Upper Miocene Samh Formation, north Marsa Alam, Red Sea, Egypt: implications for source area weathering, provenance, and tectonic setting / Samir Mahmoud Zaid // Arabian Journal of Geosciences, - 2016. - Vol. 9, Is. 12. - P. 1-15.

* This work was supported by the Science Development Foundation under the President of the Republic of Azerbaijan - Grant № EİF-KETPL-2-2015-1(25)-56/32/2

Authors Contribution: All authors have contributed equally to this work. 
UDC 622.337.2:553.98.061.17

Adil A. Aliyev,

Doctor of Sciences (Geology and Mineralogy), Professor,

Head of Department of Mud Volcanism, Institute of Geology and Geophysics,

Azerbaijan National of Academy Sciences, H. Javid ave., 119, Baku, AZ1143, Azerbaijan, e-mail: ad_aliyev@mail.ru, https://orcid.org/0000-0002-7731-9525;

Orhan R. Abbasov,

$\mathrm{PhD}$ (Earth Sciences), Associate Professor, Senior Researcher of Department of Mud Volcanism, Institute of Geology and Geophysics, Azerbaijan National of Academy Sciences,

H. Javid ave., 119, Baku, AZ1143, Azerbaijan,

e-mail: ortal80@ bk.ru, http://orcid.org/0000-0003-2135-7984;

Agamehdi M. Agayev,

$\mathrm{PhD}$ (Chemical Sciences), Associate Professor of Faculty of Geological Exploration,

Azerbaijan State Oil and Industry University, Azadlig ave., 20, AZ1010, Baku, Azerbaijan, e-mail: agamehti.agaev@gmail.com, https://orcid.org/0000-0003-1195-1971

\section{MINERALOGY AND GEOCHEMISTRY OF OIL SHALES IN AZERBAIJAN: CLASSIFICATIONS, PALAEOWEATHERING AND MATURITY FEATURES}

Shamakhi-Gobustan and Absheron regions (Azerbaijan) are a part of the South Caspian Basin, which is a subsiding basin located between the colliding of Arabian and Eurasian plates. The intensive rate of sedimentation process creates a favorable condition for the formation of oil shale, hydrocarbon and as well as mud volcanoes in these regions.

The purpose of the article. The study of oil shale in Azerbaijan has been mainly devoted to their geological and organic-geochemical characteristics, etc. However, the chemical classifications, provenience, palaeoweathering and maturity characteristics have not been studied. This study is the first attempt to investigate noted issues.

The research methodology. 10 samples from the outcrops and eject of mud volcanoes were analyzed. The concentrations of major and trace elements and minerals were measured by "S8 TIGER Series 2 WDXRF", "Agilent 7700 Series ICP-MS" mass spectrometers and XRD "MiniFlex 600". The microscopes "Loupe Zoom Paralux XTL 745" and "MC-10" and a digital camera "OptixCam" were used to determine the age of the samples.

The major and trace elements in the composition of samples were compared with average shale, NASC, PAAS and average black shale as well as oil shale from the Green River Formation of USA, Kukersit of Estonia, etc. studied in the published literature. A diagram and index were used for the classifications and determination of maturity of rocks. The palaeoweathering characteristic was determined based on CIA versus ICV and some other plots and ratios.

Research results. The minerals found in oil shale were classified according to their classes. According to the used classification diagram, it was established that all studied samples correspond to shale. A superiority of clay minerals in the composition of oil shale compared to K-minerals, including K-feldspar was found.

The estimates based on geochemistry and some ratios of elements confirm the instability of oxides and minerals, and immaturity of the samples.

The values of the CIA, CIA versus ICV plot, etc. confirm moderate to high degree of weathering. The results confirm a conclusion that the original sediments were derived from mafic and intermediate source terrain.

The scientific novelty. The scientific analysis presented in the paper is based on several substantial theoretical conclusions, which related to the factual material of research conducted by the co-authors.

The mineralogy, classification features, stability characteristics of the major oxides and minerals as well as chemical maturity and palaeoweathering were studied based on the chemical composition of the samples.

The practical significance. The results of the current study can be used for the further utilization of oil shale in Azerbaijan and the selection of promising areas in terms of mineral raw materials.

Keywords: oil shale, geochemistry, mineral, classification, maturity, weathering.

\section{References}

1. Abbasov, O. R. (2009). Distribution regularities of shales of Paleogene-Miocene sediments in Gobustan : abstract of PhD thesis ... on PhD in Earth Sciences : 26.11.09. Institute of Geology and Geophysics, Azerbaijan National Academy of Sciences, Baku, 24. 
2. Abbasov O.R., Mamedova A.N., Huseynov A.R., Baloglanov E.E. (2013). Some new data on geochemical researches of combustible slates of Azerbaijan. Geology, Geophysics and Development of Oil and Gas Fields, 2, 32-35.

3. Abbasov Orhan. (2015). Oil shale of Azerbaijan: geology, geochemistry and probable reserves. International Journal of Research Studies in Science, Engineering and Technology, 2 (9), 31-37.

4. Abbasov Orhan. (2016). Organic compounds in ejected rocks of mud volcanoes as geological and geochemical indicators of source rock: a study of oil shale in Shamakhi-Gobustan region (Azerbaijan). International Journal of Current Advanced Research, 5 (7), 1042-1046.

5. Abbasov O.R. (2016). Distribution regularities of oil shale in Azerbaijan. ISJ Theoretical \& Applied Science, 3 (35), 165-171. http://dx.doi.org/10.15863/TAS.2016.03.35.28

6. Abbasov O.R. (2017). Distribution regularities and geochemistry of oil shales in Azerbaijan. Mineral resources of Ukraine, 2, 22-30.

7. Aghayev Aghamehdi. (2006). Geochemistry of sedimentation processes. Baku: Publishing house "Adiloghlu", 136 p.

8. Alali Jamal, Abu Salah Abdelfattah, Yasin Suha M., Al Omari Wasfi. (2015). Oil Shale in Jordan. Natural Resources Authority of Jordan, $26 \mathrm{p}$.

9. Aliyev Ad.A., Belov I.S., Aliyev G.A. (2000). Oil shales of Miocene in Azerbaijan. Azrebaijan Oil Industry, 5, 7-11.

10. Aliyev Ad.A., Belov I.S., Bayramov T.A. (2003). Oil shale of Paleogene-Miocene in Azerbaijan. Geologist of Azerbaijan. Scientific Bulletin, 8, 68-80.

11. Aliyev Ad.A., Guliyev I.S., Dadashev F.G., Rahmanov R.R. (2015). Atlas of mud volcanoes in the world. Baku: Publishing house "Nafta-Press", "Sandro Teti Editore", 361 p.

12. Aliyev A.A., Abbasov O.R., IbadzadeA A.J.,Mammadova A.N. (2018). Organic-geochemical study of oil shales in Pre-Caspian-Guba region (Azerbaijan). Mineral resources of Ukraine, 3, 13-18. https://doi.org/10.31996/mru.2018.3.13-18.

13. Aliyev Adil, Abbasov Orhan. (2018). Organic geochemical characteristics of oil shale in Azerbaijan. The $36^{\text {th }} \mathrm{Na-}$ tional and the $3^{\text {rd }}$ International Geosciences Congress. Tehran, Iran, February 25-27, p. 1-10.

14. Aliyev Ad.A., Abbasov O.R., Ibadzade A.J., Mammadova A.N. (2018). Genesis and organic geochemical characteristics of oil shale in Eastern Azerbaijan. SOCAR Proceedings, 2018, 3, p. 4-15. http://dx.doi.org/10.5510/OGP20180300356.

15. Arro H., Prikk A., Pihu T. (1998). Calculation of composition of Estonian oil shale and its combustion products on the basis of heating value. Oil Shale, 15 (4), 329-340.

16. Cingolani C.A., Manassero M., Abre P. (2003). Composition, provenance, and tectonic setting of Ordovician siliciclastic rocks in the San Rafael block: Southern extension of the Precordillera crustal fragment, Argentina. Journal of South American Earth Sciences, 16 (1), 91-106. https://doi.org/10.1016/S0895-9811(03)00021-X.

17. Connie L. Wilkerson. (1982). Trace metal composition of Green River retorted shale oil. Fuel, 61 (1), $63-70$. https://doi.org/10.1016/0016-2361(82)90294-0.

18. Cox R., Lowe D.R., Cullers R.L. (1995). The influence of sediment recycling and basement composition of evolution of mudrock chemistry in the Southwestern United States. Geochimica et Cosmochimica Acta, 59, $2919-2940$. http://dx.doi.org/10.1016/0016-7037(95)00185-9.

19. Cullers R.L. (2000). The geochemistry of shales, siltstones and sandstones of Pennsylvanian-Permian age, Colorado, USA: implications for provenance and metamorphic studies. Lithos, 51, $181-203$. https://doi.org/10.1016/S0024-4937(99)00063-8.

20. Farquhar S.M., Pearce J.K., Dawson G.K.W., Golab A., Sommacal S., Kirste D., Biddle D., Golding S.D. (2014). A fresh approach to investigating $\mathrm{CO}_{2}$ storage: experimental $\mathrm{CO}_{2}$-water-rock interactions in a low-salinity reservoir system. Chemical Geology, 1-70. https://doi.org/10.1016/j.chemgeo.2014.10.00.

21. Fedo C.M., Nesbitt H.W., Young G.M. (1995). Unraveling the effects of potassium metasomatism in sedimentary rocks and paleosols, with implications for weathering conditions and provenance. Geology, 23, $921-924$. https://doi.org/10.1130/0091-7613(1995)023<0921:UTEOPM>2.3.CO;2

22. Aliyev Ad.A., Aliyev Ch.S., Feyzullayev A.A., et al. (2015). Geology of Azerbaijan, II Volume. Baku: Publishing house "Elm", 341.

23. Gharrabi M., Velde B., Sagon J.-P. (1998). The transformation of illite to muscovite in pelitic rocks: Constraints from $X$-ray diffraction. Clays and Clay Minerals, 46, 79-88.

24. Gill S., Yemane K. (1996). Implications of a lower Pennsylvanian Ultisol for equatorial Pangean climates and early, oligotrophic, forest ecosystems. Geology, 24 (10), 905-908. https://doi.org/10.1130/00917613(1996)024<0905:IOALPU>2.3.CO;2.

25. Gromet L.P., Dymek R.F., Haskin L.A., Korotev R.L. (1984). The "North American shale composite" its compilation, major, and trace elements characteristics. Geochimica et Cosmochimica Acta, 48, $2469-2482$. https://doi.org/10.1016/0016-7037(84)90298-9.

26. Hawkins P.J. (1978). Relationship between diagenesis, porosity reduction and oil replacement in Late Carbonifereous sandstone reservoirs, Bothamsall oil field, E. Midlands. Jour. Geol. Soc. London, 135, 7-24. https://doi.org/10.1144/gsjgs.135.1.0007.

27. Herron M.M. (1988). Geochemical classification of terrigenous sands and shales from core and log data. Journal of Sedimentary Petrology, 58, 820-829. 
28. Kondrasheva N.K. (2016). Assessment of the possibility of using oil shale and shale-ash waste in industry. Notes of the Mining Institute, 220, 595-600.

29. Kortenski J., Sotirov A. (2002). Trace and major elements content and distribution in Neogene lignite from the Sofia Basin, Bulgaria. International Journal of Coal Geology, 52, 63-82.

30. Kler V.R., Volkova G.A., Gurvich E.M. et al. (1988). Metallogeny and geochemistry of coal bearing and shale bearing strata of the USSR: regularities of elements concentration and study methods). Moscow: Nauka, $256 \mathrm{p}$.

31. Long X., Yuan C., Sun M., Xiao W., Wang Y., Cai K, Jiang Y. (2012). Geochemistry and Nd isotopic composition of the Early Paleozoic flysch sequence in the Chinese Altai, Central Asia: Evidence for a northward-derived mafic source and insight into Nd model ages in accretionary orogen. Gondwana Research, 22, 554-566. https://doi.org/10.1016/j.gr.2011.04.009.

32. Martin J.H., Knauer G.A. (1973). The Elemental Composition of Plankton. Geochimica et Cosmochimica Acta, 37, 1639-1653. https://doi.org/10.1016/0016-7037(73)90154-3.

33. Nelson Stephen A. (2014). Tectosilicates, carbonates, oxides, \& accessory minerals. Mineralogy, 15 p.

34. Nesbitt H.W., Markovics G., Price R.C. (1980). Chemical processes affecting alkalis and alkaline earths during continental weathering. Geochimica et Cosmochimica Acta, 44,1659-1666. https://doi.org/10.1016/00167037(80)90218-5.

35. Nesbitt H.W., Young G.M. (1982). Early Proterozoic climates and plate motion inferred from major element chemistry of Lutites. Nature, 299, 715-717.

36. Nesbitt H.W., Young G.M. (1984). Prediction of some weathering trends of plutonic and volcanic rocks based on thermodynamic and kinetic considerations. Geochimica et Cosmochimica Acta, 48, $1523-1534$. https://doi.org/10.1016/0016-7037(84)90408-3.

37. Obasi R.A., Madukwe H.Y. (2016). Use of geochemistry to study the provenance, tectonic setting, source-area weathering and maturity of Igarra Marble, Southwest, Nigeria. American Journal of Engineering Research, 5 (6), 90-99.

38. Onal M., Ayyildiz T., Onal Y., Akmil-Bashar C. (2006). Stratigraphic, mineralogic and geochemical characterization of Gürün oil shales, central Anatolia, Turkey. Oil Shale, 23 (4), 297-312.

39. Pettijohn F.J., Potter P.E., Siever R. (1987). Sand and Sandstone. Springer, 213.

40. Potter P.E. (1978). Petrology and chemistry of modern big river sands. The Journal of Geology, 86 (4), $423-449$.

41. Aliyev Ad.A., Bayramov A.A., Abbasov O.R., Mammadova A.N. (2014). Reserves of oil shale and natural bitumen. National Atlas of the Republic of Azerbaijan, Map (Scale 1:1000000), 101.

42. Rodrigo D.L., Luiz F.D.R. (2002). The role of depositional setting and diagenesis on the reservoir quality of Devonian sandstones from the Solimones Basin, Brazilian Amazonia. Marine and Petroleum Geology, 19, $1047-1071$.

43. Servaraj K., Arthur C.C. (2006). Moderate chemical weathering of subtropical Taiwan: constraints fromsolid-phase geochemistry of sediments and sedimentary rocks. Journal of Geology, 114, 101-116.

44. Shener M., Shenguler I. (1998). Geological, mineralogical and geochemical characteristics of oil shale bearing deposits in the Hatildag oil shale field, Göynük, Turkey. Fuel, 8, 871-880.

45. Tank R.W. (1972). Clay minerals of the Green River Formation (Eocene) of Wyoming. Clay Minerals, 9, $297-308$.

46. Taylor S.R., McLennan S.M. (1985). The continental crust: its composition and evolution. Oxford: Blackwell, 312 p. https://doi.org/10.1002/gj.3350210116.

47. Turekian K.K., Wedepohl K.H. (1961). Distribution of the Elements in some major units of the Earth's crust. Geological Society of America, Bulletin, 72, 175-192.

48. Urov K., Sumberg A. (1999). Characteristics of oil shales and shale-like rocks of known deposits and outcrops. Oil shale, 16 (3), 1-64.

49. Vine J.D., Tourtelot E.B. (1970). Geochemistry of black shale deposits. Economic Geology and the Bulletin of the Society of Economic Geologists, 65, 253-272. https://doi.org/10.2113/gsecongeo.65.3.253.

50. Weaver C.E., Beck K.C., Pollard C.O. (1971). Clay water diagenesis during burial: how mud becomes gneiss. Special Papers - Geological Society of America, 134, 1-78.

51. Samir Mahmoud Zaid, Fahad AL Gahtani. (2015). Provenance, diagenesis, tectonic setting, and geochemistry of Hawkesbury Sandstone (Middle Triassic), southern Sydney Basin, Australia. Turkish Journal of Earth Sciences, 24, 72-98. https://doi.org/10.3906/yer-1407-5.

52. Samir M. Zaid. (2016). Geochemistry of shales from the Upper Miocene Samh Formation, north Marsa Alam, Red Sea, Egypt: implications for source area weathering, provenance, and tectonic setting. Arabian Journal of Geosciences, 9 (12), $1-15$. 